\title{
Morphological and genetic variation in Leggadina (Thomas, 1910) with special reference to Western Australian populations
}

\author{
N. K. Cooper ${ }^{1}$, M. Adams ${ }^{2,3}$, C. Anthony ${ }^{1}$ and L. H. Schmitt ${ }^{4}$ \\ ${ }^{1}$ Mammal Department, Western Australian Museum, Francis Street, Perth, Western Australia 6000 \\ (address for correspondence). Email: norah.cooper@museum.wa.gov.au \\ ${ }^{2}$ Evolutionary Biology Unit, South Australian Museum, Adelaide, South Australia 5000 \\ ${ }^{3}$ Centre for Evolutionary Biology and Biodiversity, University of Adelaide, \\ Adelaide, South Australia 5005 \\ ${ }^{4}$ School of Anatomy and Human Biology, The University of Western Australia, \\ 35 Stirling Highway, Crawley, Western Australia 6009
}

\begin{abstract}
Recent collections of specimens from the Pilbara attributed to Leggadina lakedownensis stimulated an investigation of genetic and morphometric variation in $L$. lakedownensis and $L$. forresti to confirm the taxonomic status of these species, determine the extent of intraspecific variation, and develop useful markers for classification. Extensive analyses of both morphology and allozymes confirm the clear taxonomic separation of these two species. Leggadina lakedownensis shows considerably more intraspecific morphological variation than $L$. forresti, reflecting the former's much greater geographic range and ecological diversity. The mean body size of Thevenard Island L. lakedownensis is markedly larger than the other populations examined. Despite this morphological diversity, populations of L. lakedownensis, including those from mainland Pilbara and Thevenard Island, are genetically similar across their range. An individual from Queensland is genetically the most divergent but we have been unable to assess the morphological relationship of the topotypical population.
\end{abstract}

\section{INTRODUCTION}

The genus Leggadina has a wide distribution across mainland Australia, with two allopatric species currently recognised, L. forresti (Thomas, 1906) from central Australia and L. lakedownensis (Watts, 1976), broadly distributed across northern Australia (Figure 1). Baverstock et al. (1976) presented biochemical and karyotypic evidence to firmly establish the specific distinction of L. lakedownensis, then known only from a restricted area of northeast Queensland, from the more widely distributed Leggadina forresti.

Since these initial studies, many different populations of Leggadina have been sampled, especially in the Kimberley and Pilbara regions of Western Australia. Although some of these populations have been referred to L. lakedownensis, this attribution has not been critically examined. In addition, animals from Thevenard Island, off the Pilbara coast, are much larger than mainland populations of Leggadina, and this has led to some concern over the taxonomic status and conservation needs of this morphologically-distinctive form. Moro et al. (1998) examined variation in mitochondrial DNA (mtDNA) from Western Australia and Northern Territory populations referred to Leggadina lakedownensis and found significant lineage divergence between the Pilbara (including Thevenard Island) and Kimberley populations of this species. On this basis they suggested that the Pilbara and Thevenard Island specimens together might represent a distinct subspecies. Moro et al. (1998) did not include any specimens from northeast Queensland in their analyses.

Prior to 1997, only two specimens of Leggadina had been collected in the Pilbara region. Since that time, thirty specimens, some with tissue for molecular analysis, have been collected during various surveys of the region. The availability of this new material has prompted us to conduct a comprehensive morphological and genetic study of Leggadina across its geographic range. The purposes of this study were to re-assess species boundaries in the genus using morphological and allozyme data, and to examine broader patterns of morphological and genetic variation across the range of $L$. lakedownensis. 


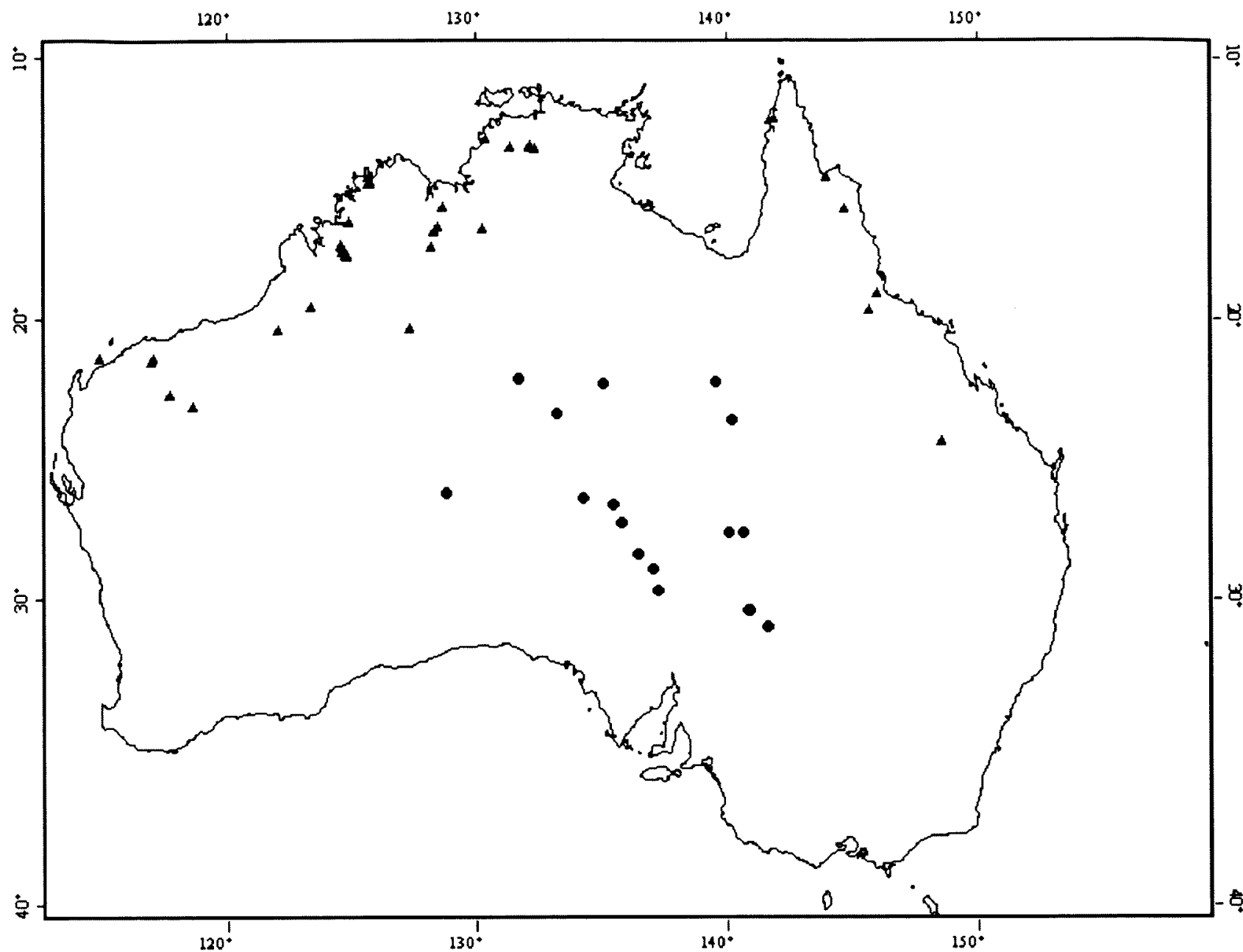

Figure 1 Distribution of Leggadina, with localities for specimens used in this study marked, (A) L. lakedownensis, (O) L. forresti.

\section{MATERIALS AND METHODS}

\section{Allozyme characterization}

Genetic analysis was based on tissue samples from 16 specimens of Leggadina lakedownensis, aggregated into six populations according to geographic location, and 12 specimens of $L$. forrest $i$ (Appendix 1). Liver samples for allozyme electrophoresis were removed from freshly killed animals in the field or at the Western Australian Museum and immediately frozen in liquid nitrogen before being stored at $-80^{\circ} \mathrm{C}$. Allozyme electrophoresis of liver homogenates was conducted on cellulose acetate gels ('Cellogel') according to the methods of Richardson et al. (1986). The following proteins exhibited zymograms of sufficient activity to assign genotypes: aconitase hydratase (ACON, EC 4.2.1.3), aminoacylase (ACYC, EC 3.5.1.14), adenosine deaminase (ADA, EC 3.5.4.4), alcohol dehydrogenase (ADH, EC 1.1.1.1), adenylate kinase (AK, EC 2.7.4.3), albumen (ALB), carbonate dehydratase (CA, EC 4.2.1.1), diaphorase (DIA, EC 1.6.99.), enolase (ENOL, EC 4.2.1.11), fructose-bisphosphatase (FDPASE, EC
3.1.3.11), fumarate hydratase (FUM, EC 4.2.1.2), glyceraldehyde-3-phosphate dehydrogenase (GAPD, EC 1.2.1.12), lactoylglutathione lyase (GLO, EC 4.4.1.5), aspartate aminotransferase (GOT, EC 2.6.1.1), glucose-6-phosphate dehydrogenase (G6PD, EC 1.1.1.49), glycerol-3-phosphate dehyrogenase (GPD, EC 1.1.1.8), glucose-6phosphate isomerase (GPI, EC 5.3.1.9), glutathione peroxidase (GPX, EC 1.11.1.9), glutathione reductase (GSR, EC 1.6.4.2), isocitrate dehydrogenase (IDH, EC 1.1.1.42), L-lactate dehydrogenase (LDH, EC 1.1.1.27), malate dehydrogenase (MDH, EC 1.1.1.37), "malic" enzyme (ME, EC 1.1.1.40), mannose-6-phosphate isomerase (MPI, EC 5.3.1.8), purine-nucleoside phosphorylase (NP, EC 2.4.2.1), dipeptidase (PEPA, EC 3.4.13.), tripeptide aminopeptidase (PEP-B, EC 3.4.11.), proline dipeptidase (PEP-D, EC 3.4.13.), phosphoglycerate mutase (PGAM, EC 5.4.2.1), phosphogluconate dehydrogenase (6PGD, EC 1.1.1.44), phosphoglycerate kinase (PGK, EC 2.7.2.3), phosphoglucomutase (PGM, EC 5.4.2.2), pyruvate kinase (PK, EC 2.7.1.40), superoxide dismutase (SOD, EC 1.15.1.1), and triose-phosphate 
isomerase (TPI, EC 5.3.1.1). The nomenclature for designating allozymes and multiple loci follows Adams et al. (1987).

A phylogenetic analysis using all specimens from both species was undertaken by constructing a neighbor-joining tree (Saitou and Nei, 1987) of Nei (1978) unbiased genetic distance. Because the populations of L. lakedownensis could potentially be interbreeding we also investigated their genetic relationships by a principal coordinates analysis (Gower, 1966) using the Cavalli-Sforza and Edwards (1967) arc distance matrix which is Euclidean. These analyses were carried out using Genstat (2000), Biosys-1 (Swofford and Selander, 1989) and Mega version 2.1 (Kumar et al., 2001).

\section{Morphological characterization}

Morphological analysis was based on 132 specimens, of which 108 were attributable to
L. lakedownensis and aggregated into eight geographic populations, and the remainder (24) spread across most of the geographic range of L. forresti (Appendix 2). Skulls of L. lakedownensis from Queensland were not available for measurement until after the morphological analysis was completed. From the analysis, the significance of the length of the upper molar row was realised and then these measurements of the Queensland specimens were taken, though this group was not used in any multivariate statistical analyses. Skulls from Fowlers Gap and Innamincka (SAM13633, SAM10170) identified as L. forresti by Baverstock $e t$ al. (1976) using karyotypic and biochemical analyses were included herein, as were skulls from Oodnadatta, Birdsville, MacDonald Ranges and Southwest Mann Range (M21623, M21762, M21786, M6344, and M6345), also identified as L. forresti by Watts (1976) using morphology.
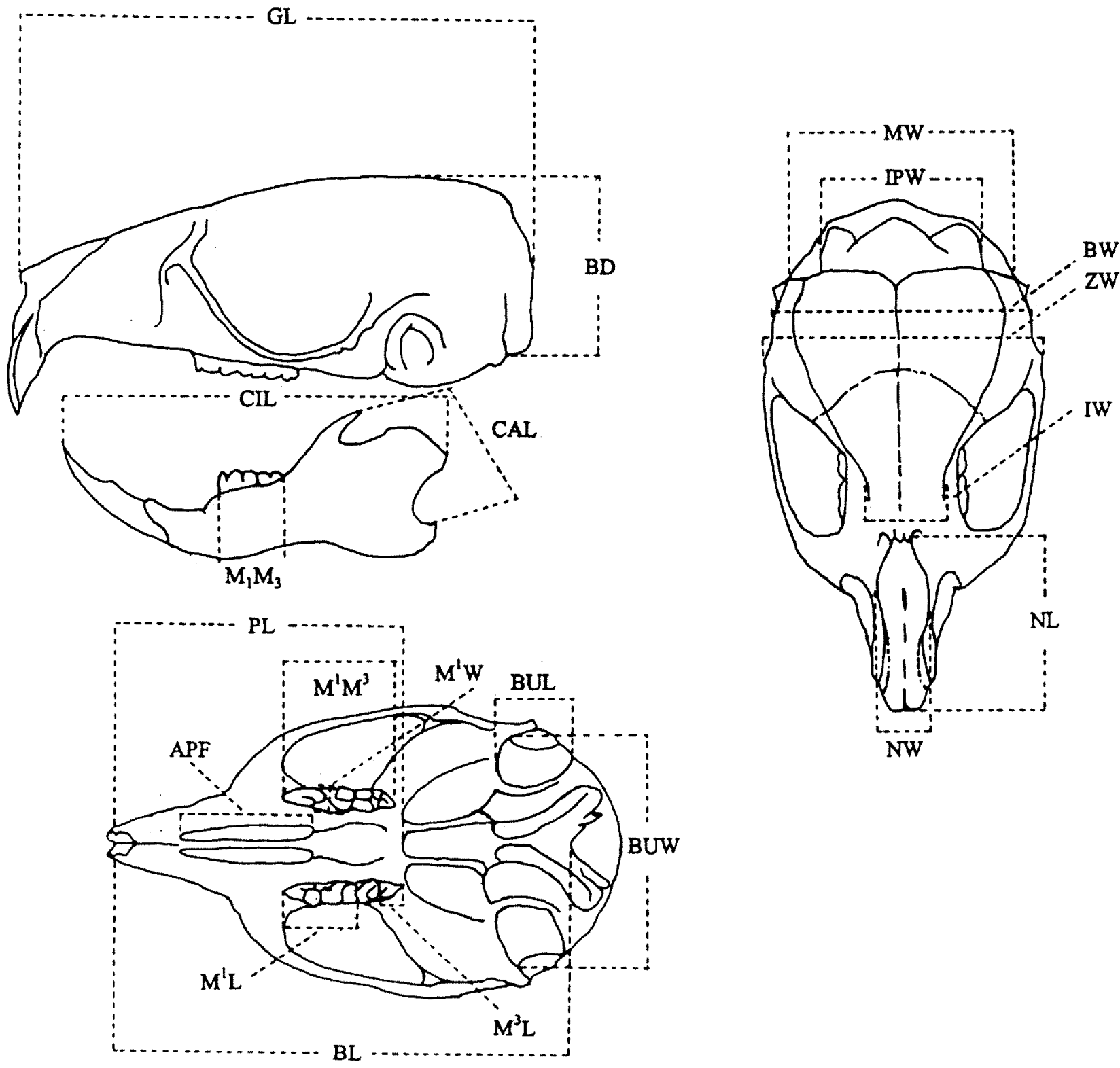

Figure 2 Skull measurement points. 
Twenty measurements of skull, dentary and dental characters and six measurements of external characters (Figure 2) were recorded to the nearest $0.01 \mathrm{~mm}$ using digital callipers. The measurements were GL, greatest skull length; $B D$, braincase depth; IPW, interparietal width; BW, braincase width; ZW, zygomatic width; IW, interorbital width; NL, nasal length; NW, nasal width; MW, mastoid width; BUW, width across bullae; BL, basal skull length; $M^{1} \mathrm{~L}$, upper molar 1 length; $\mathrm{M}^{3} \mathrm{~L}$, upper molar 3 length; $M^{1} W$, upper molar 1 width; $M^{1} M^{3} L$, length of upper molar row; APF, anterior palatal foramen length; $\mathrm{PL}$, palatal length; $\mathrm{CIL}$, dentary condyle to tip of incisor; $\mathrm{CAL}$, tip of coronoid process to posterior edge of angular process; $M_{1} M_{3} L$, lower molar row length. The external measurements were HV, head to vent; TV, vent to tail tip; TAILW, tail diameter measured close to body; PESW, width of pes at hallux; PESL, pes length; EARL, ear length.

$\mathrm{M}^{2} \mathrm{~L}$ was not measured during this study because its significance in differentiating between $L$. lakedownensis and $L$. forrest $i$ was not appreciated at the time of measurement, it was later calculated as $\mathrm{M}^{1} \mathrm{M}^{3} \mathrm{~L}-\mathrm{M}^{1} \mathrm{~L}-\mathrm{M}^{3} \mathrm{~L}$.

Individuals were categorised into three age groups, mature, adult and juvenile according to the extent of tooth-wear and fusion of cranial sutures; mature - extensive tooth wear and sutures fused, adult- some tooth wear and most sutures fused and juveniles- tooth eruption, no tooth wear and sutures unfused. Age was confirmed by examination of the external reproductive status of the animal, fully descended testes or nipple development representing adults and minimal testes descent and button nipples representing juveniles. Three individuals were classified into juvenile and were excluded from all analyses. Appendix 3 lists summary statistics for 20 skull and 6 external variables in L. lakedownensis (grouped by geographical region) and L.forresti, (all localities pooled).

Initially, we used multiple regressions to investigate and remove any effects of age and sex before further multivariate analyses. These analyses also permitted the detection of statistical outliers and non-normality. For L. lakedownensis, each character was regressed on sex, age and locality, and the interactions between these factors. The interactions were examined first because they test for the inter-dependence of the three factors. CAL was the only cranial variable that had a significant interaction (between age and locality). This was a consequence of mean differences between the adults and mature age classes varying between localities. There was also a significant two-way interaction for TAILW $(p<0.01)$; there was no obvious fat storage in tails. These two variables were not used in any further multivariate analyses. Four variables showed statistically significant sexual dimorphism at the $5 \%$ level of significance (see results) and most variables revealed statistically significant differences between age classes and between localities. We therefore used the estimates of the regression coefficients to remove the age and sex differences while retaining the inter-locality variation. Male and female values were adjusted to the mean of the two sexes, and mature and adult values to the mean of these two age classes. For $L$. forresti, there were not enough individuals of both sexes and each age group to test for interactions or reliably estimate main effects, so sexual dimorphism and age differences in this species were corrected by using the regression estimates made from L. lakedownensis. All analysis were repeated with $L$. forrest $i$ variables corrected for sex and age effects using regression estimates made from $L$. forresti and results were unchanged.

Canonical variate analysis (discriminant analysis) was used to determine the multivariate relationships between groups. Where a subset of characters was required, they were selected by sequential multivariate analysis of variance, using backward elimination and Wilks' lambda as the selection criteria. All statistical analyses were carried out using Genstat (2000).

\section{RESULTS}

\section{Interspecies comparison}

Allelic variation was observed at 24 of the 44 putative genetic loci examined (Table 1). The genetic data unequivocally diagnosed L. lakedownensis from L. forresti, with fixed differences at seven loci (Acon1, Enol, Fdp, G6pd, Got1, Gsr, and Mdh2) and major differences in allele frequency at another three loci (Adh1, Gda, and Sod). The unbiased Nei Distance between the species is about 0.28 , indicating marked genetic differentiation (Table 2 and Figure 3). In contrast, regional populations of L. lakedownensis showed minimal differentiation, with no pairwise Nei Distance greater than 0.033 (Table 2), and only one locus showed any evidence of genetic heterogeneity (ie. a deficiency of heterozygotes) in L. forresti (Ada, data not shown).

The initial morphological appraisal examined the relationship between $L$. lakedownensis and $L$. forrest $i$ by canonical variate analysis of cranial measures to confirm the specific status of these taxa. While there is no overlap in the distribution of the two species on the canonical variate, two L. lakedownensis are positioned closer to the L. forresti centroid than their own species and so are incorrectly allocated to the wrong species (Figure 4). Because the sample size of $L$. forresti was small, only five traits, selected by backward elimination, were used in this analysis. The canonical variate is a contrast of upper molar 1 
Table 1 Sample size for genetic analysis $(N)$, putative allele frequencies at 24 variable loci, and mean heterozygosity (H) in 6 populations of $L$. lakedownensis and in L. forresti. The following 20 loci were invariant:- $A k 1, A k 2, A l b$, Fum, Gapd, Glo, Gpd, Gpi, Gpx, Idhl, Ldhl, Ldh2, Mdhl, Me, Np, PepAl, PepB, Pgk, Pgm1, and Tpi.

\begin{tabular}{|c|c|c|c|c|c|c|c|c|}
\hline \multirow[b]{2}{*}{ Locus } & \multirow[b]{2}{*}{ Allele } & \multicolumn{6}{|c|}{ L. lakedownensis } & \multirow[t]{2}{*}{ L. forresti } \\
\hline & & Pilbara & $\begin{array}{l}\text { Thevenard } \\
\text { Island }\end{array}$ & $\begin{array}{l}\text { Mitchell } \\
\text { Plateau }\end{array}$ & Lissadell & Kakadu & Queensland & \\
\hline$N$ & & 6 & 1 & 3 & 2 & 3 & 1 & 12 \\
\hline \multirow{2}{*}{ Aconl } & $\mathrm{a}$ & - & - & - & - & - & - & 1.00 \\
\hline & $b$ & 1.00 & 1.00 & 1.00 & 1.00 & 1.00 & 1.00 & - \\
\hline \multirow[t]{3}{*}{ Acon 2} & a & - & - & - & - & - & - & 0.04 \\
\hline & $\mathrm{b}$ & 1.00 & 1.00 & 0.83 & 1.00 & 1.00 & 1.00 & 0.88 \\
\hline & c & - & - & 0.17 & - & - & - & 0.08 \\
\hline \multirow[t]{3}{*}{ Acyc } & a & - & - & 0.17 & - & - & - & 0.04 \\
\hline & $b$ & 0.92 & 1.00 & 0.83 & 0.75 & 0.67 & 1.00 & 0.92 \\
\hline & c & 0.08 & - & - & 0.25 & 0.33 & - & 0.04 \\
\hline \multirow[t]{3}{*}{$A d a$} & a & 1.00 & 1.00 & 1.00 & 1.00 & 1.00 & 1.00 & 0.42 \\
\hline & $b$ & - & - & - & - & - & - & 0.50 \\
\hline & c & - & - & - & - & - & - & 0.08 \\
\hline \multirow[t]{2}{*}{ Adhl } & a & - & - & - & - & - & - & 0.88 \\
\hline & b & 1.00 & 1.00 & 1.00 & 1.00 & 1.00 & 1.00 & 0.12 \\
\hline \multirow[t]{3}{*}{ Adh 2} & a & 0.08 & - & - & - & - & - & - \\
\hline & b & 0.92 & 1.00 & 1.00 & 0.75 & 0.83 & 1.00 & 1.00 \\
\hline & c & - & - & - & 0.25 & 0.17 & - & - \\
\hline \multirow[t]{2}{*}{$\mathrm{Ca}$} & a & 0.17 & - & - & - & - & - & 0.12 \\
\hline & b & 0.83 & 1.00 & 1.00 & 1.00 & 1.00 & 1.00 & 0.88 \\
\hline \multirow[t]{2}{*}{ Dia } & $\mathrm{a}$ & 1.00 & 1.00 & 1.00 & 1.00 & 1.00 & 1.00 & 0.92 \\
\hline & b & - & - & - & - & - & - & 0.08 \\
\hline \multirow[t]{2}{*}{ Enol } & a & - & - & - & - & - & - & 1.00 \\
\hline & $b$ & 1.00 & 1.00 & 1.00 & 1.00 & 1.00 & 1.00 & - \\
\hline \multirow[t]{2}{*}{$F d p$} & a & - & - & - & - & - & - & 1.00 \\
\hline & $b$ & 1.00 & 1.00 & 1.00 & 1.00 & 1.00 & 1.00 & - \\
\hline \multirow[t]{2}{*}{ G6pd } & $\mathrm{a}$ & 1.00 & 1.00 & 1.00 & 1.00 & 1.00 & 1.00 & - \\
\hline & b & - & - & - & - & - & - & 1.00 \\
\hline \multirow[t]{2}{*}{$G d a$} & a & - & - & - & - & - & - & 0.88 \\
\hline & b & 1.00 & 1.00 & 1.00 & 1.00 & 1.00 & 1.00 & 0.12 \\
\hline Gotl & a & - & - & - & 0.50 & - & - & 1.00 \\
\hline & b & 1.00 & 1.00 & 1.00 & 0.50 & 1.00 & 1.00 & - \\
\hline Got2 & a & 1.00 & 1.00 & 1.00 & 1.00 & 1.00 & 1.00 & 0.96 \\
\hline & b & - & - & - & - & - & - & 0.04 \\
\hline Gsr & $\mathrm{a}$ & 0.08 & - & - & - & - & - & - \\
\hline & $\mathrm{b}$ & - & - & - & - & - & - & 1.00 \\
\hline & c & 0.92 & 1.00 & 1.00 & 1.00 & 1.00 & 1.00 & - \\
\hline Idh 2 & $a$ & 0.92 & 1.00 & 1.00 & 1.00 & 1.00 & 1.00 & 1.00 \\
\hline & $b$ & 0.08 & - & - & - & - & - & - \\
\hline$M d h 2$ & a & - & - & - & - & - & $\ldots$ & 1.00 \\
\hline & b & 1.00 & 1.00 & 1.00 & 1.00 & 1.00 & 1.00 & - \\
\hline$M p i$ & a & - & - & - & - & - & - & 0.08 \\
\hline & $\mathrm{b}$ & 1.00 & 1.00 & 1.00 & 1.00 & 1.00 & 1.00 & 0.92 \\
\hline PepA2 & a & - & - & 0.17 & 0.25 & - & - & - \\
\hline & b & 1.00 & 1.00 & 0.83 & 0.75 & 1.00 & 1.00 & 1.00 \\
\hline PepD & $\mathrm{a}$ & - & - & 0.33 & - & - & - & - \\
\hline & $\mathrm{b}$ & 1.00 & 1.00 & 0.67 & 1.00 & 1.00 & 1.00 & 1.00 \\
\hline Pgam & a & - & - & - & - & - & - & 0.04 \\
\hline & $\mathrm{b}$ & 1.00 & 1.00 & 1.00 & 1.00 & 1.00 & 1.00 & 0.96 \\
\hline $6 \mathrm{Pgd}$ & a & - & - & - & 0.25 & 0.67 & - & 0.75 \\
\hline & b & 1.00 & 1.00 & 1.00 & 0.75 & 0.33 & 0.50 & 0.25 \\
\hline & $c$ & - & - & - & - & - & 0.50 & - \\
\hline$P k$ & a & 1.00 & 1.00 & 1.00 & 1.00 & 1.00 & - & 1.00 \\
\hline & b & - & - & - & - & - & 1.00 & - \\
\hline Sod & $\mathrm{a}$ & - & - & - & 0.25 & - & - & 1.00 \\
\hline & $b$ & 1.00 & 1.00 & 1.00 & 0.75 & 1.00 & 1.00 & - \\
\hline $\mathrm{H}$ & & 0.022 & 0.000 & 0.035 & 0.072 & 0.032 & 0.023 & 0.058 \\
\hline
\end{tabular}




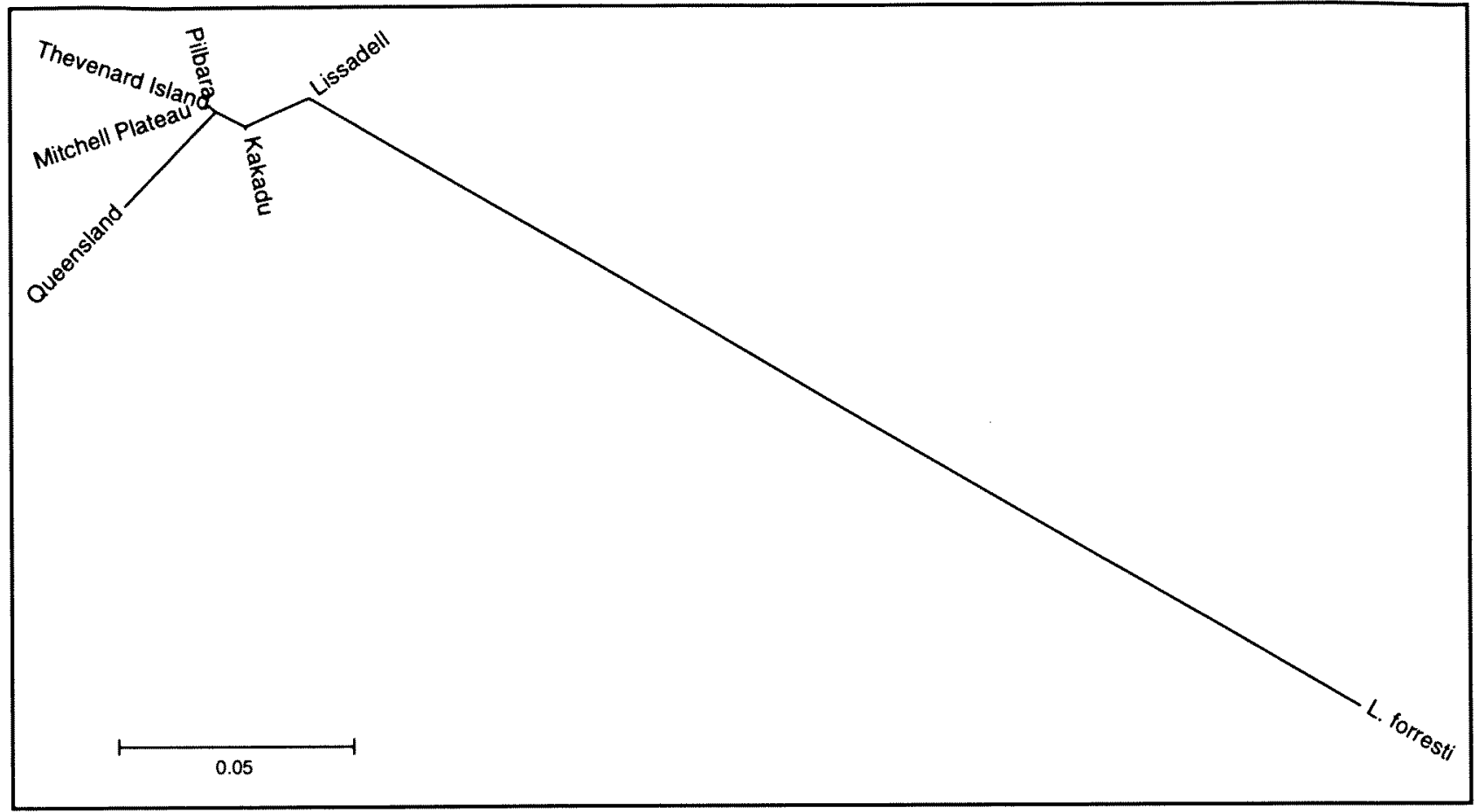

Figure 3 Neighbor-joining tree based on unbiased Nei genetic distance between six populations of L. lakedownensis and L. forresti.

Table 2 Genetic distances amongst populations of L. lakedownensis plus L. forresti. Nei unbiased distance at bottom left and Cavalli-Sforza and Edwards arc distance above and right.

\begin{tabular}{lccccccc}
\hline & Pilbara & $\begin{array}{c}\text { Thevenard } \\
\text { Island }\end{array}$ & $\begin{array}{c}\text { Mitchell } \\
\text { Plateau }\end{array}$ & Lissadell & Kakadu & Queensland & $L$.forresti \\
\hline Pilbara & - & 0.069 & 0.115 & 0.142 & 0.122 & 0.182 & 0.481 \\
Thevenard Island & 0.000 & - & 0.092 & 0.135 & 0.116 & 0.169 & 0.481 \\
Mitchell Plateau & 0.002 & 0.001 & - & 0.150 & 0.147 & 0.192 & 0.486 \\
Lissadell & 0.003 & 0.003 & 0.002 & - & 0.112 & 0.215 & 0.447 \\
Kakadu & 0.010 & 0.011 & 0.011 & 0.001 & - & 0.200 & 0.473 \\
Queensland & 0.030 & 0.029 & 0.031 & 0.031 & 0.033 & - & 0.507 \\
L.forresti & 0.278 & 0.278 & 0.285 & 0.236 & 0.266 & 0.308 & - \\
\hline
\end{tabular}

length $\left(M^{1} L\right)$ with the other four traits (Table 3). An equivalent analysis using five external measures revealed poor separation of the two species. Furthermore, 20 of 78 L. lakedownensis and one of eight $L$. forresti specimens were incorrectly allocated.

\section{Geographic variation within L. lakedownensis}

Principal coordinates analysis of the six L. lakedownensis populations revealed three genetic clusters, namely (a) Queensland, (b) Lissadell and Kakadu, and (c) the Pilbara, Thevenard Island and Mitchell Plateau populations (Figure 5). This outcome can be seen in the genetic distance values, with minimal genetic differentiation between the three Western Australian populations and between the two Northern Territory populations (all Nei Distances $<0.003$, Table 2 ).

Multiple regressions of skull and external measurements revealed that only four variables

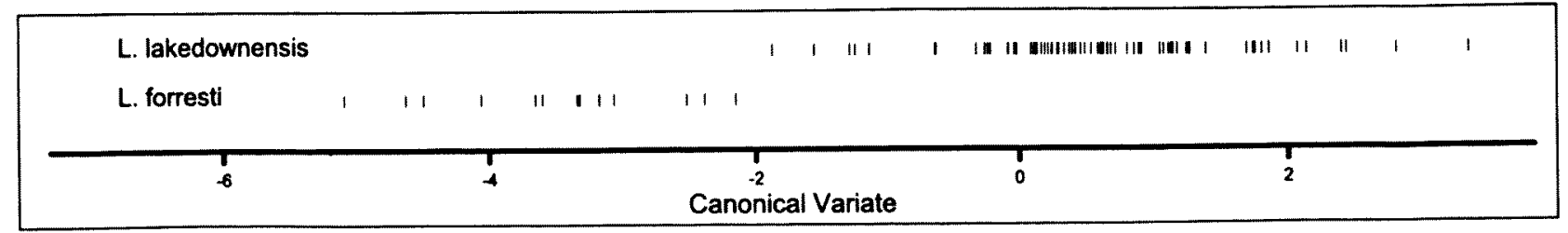

Figure 4 Plot of individuals on the canonical variate discriminating L. lakedownensis and L. forresti. 


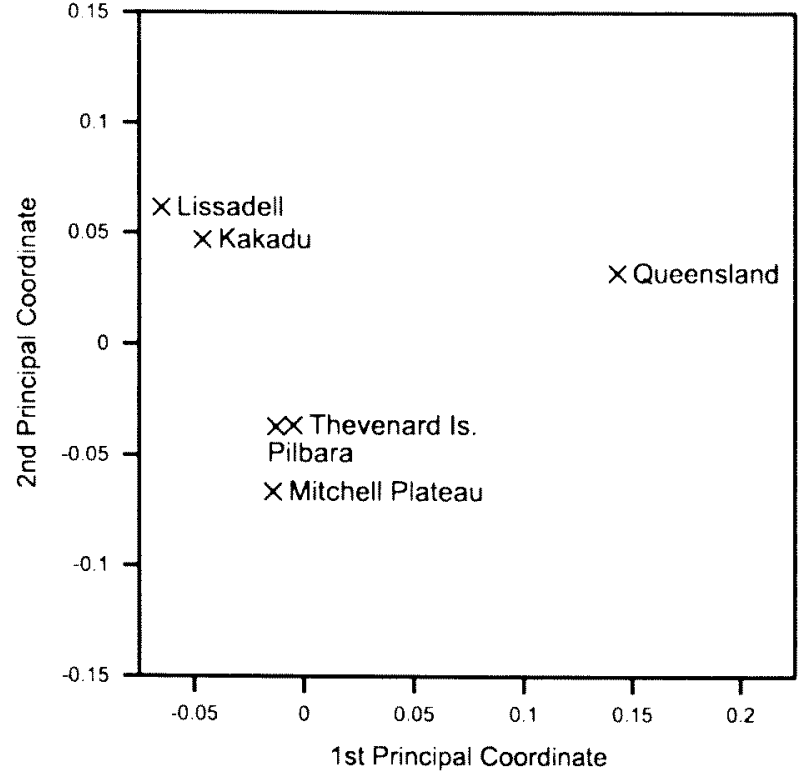

Figure 5 Scatter plot of first two components from a principal coordinates analysis of the arc genetic distance matrix for six L. lakedownensis populations.

Table 3 Correlations between original cranial measures and canonical variate for discriminant analysis of L. lakedownensis and L. forresti.

\begin{tabular}{ll}
\hline Trait & Correlation \\
\hline BD & -0.43 \\
BL & -0.35 \\
$\mathrm{M}^{1} \mathrm{~L}$ & 0.36 \\
$\mathrm{M}^{1} \mathrm{M}^{3} \mathrm{~L}$ & -0.12 \\
$\mathrm{CIL}$ & -0.12 \\
\hline
\end{tabular}

showed statistically significant sexual dimorphism $(0.01<p<0.05$ for all four variables $)$. The male MW average was $0.16 \mathrm{~mm}$ less than females; male BUW average was $0.15 \mathrm{~mm}$ less than females; and males had a broader and shorter pes compared to females (PESW 0.19 larger and PESL 0.48 smaller). Most morphometric variables revealed statistically significant differences between age classes and between localities. All variables except APF showed statistically significant differences between localities, most at the 0.001 level. Individuals of L. lakedownensis from Thevenard Island and Pilbara mainland localities were larger than individuals from every other locality (Appendix 3).

Canonical variate analysis using cranial measures for the seven localities revealed the Pilbara and Thevenard island populations clustered separately from the other five locations in northern Australia (Figure 6). This analysis was based on five traits selected by backward elimination, but essentially the same results were obtained using all 19 cranial measures or forward selection of the five best (which produced four of the same traits as
Table 4 Correlations between cranial measures and the first and second canonical variates (CV 1 and CV 2) for seven L. lakedoronensis localities.

\begin{tabular}{lcc} 
Trait & CV 1 & CV 2 \\
\hline BUW & 0.71 & -0.33 \\
BL & 0.53 & 0.24 \\
M'L & 0.30 & 0.26 \\
M $^{1} W$ & 0.74 & 0.57 \\
CIL & 0.38 & 0.36 \\
\hline
\end{tabular}

Table 5 Correlations between external measures and the first and second canonical variates (CV 1 and $C V$ 2) for seven L. lakedownensis localities.

\begin{tabular}{lcc}
\hline Trait & CV 1 & CV 2 \\
\hline HV & 0.21 & -0.28 \\
TV & 0.79 & -0.54 \\
PESW & 0.38 & 0.43 \\
PESL & 0.66 & 0.46 \\
EARL & 0.13 & 0.31 \\
\hline
\end{tabular}

backward selection). The first two canonical variates accounted for $73 \%$ and $17 \%$ of the between group variance (Table 4). The uniformly positive correlations between the five traits and the first canonical function show that this is largely a size discriminator, accounting for the separation of the Pilbara and Thevenard Island populations from the others on this axis. The second canonical variate is a contrast of width across bullae and the other four traits, especially width of $\mathrm{M}^{1}$.

A parallel analysis using the five external features clearly separated the Thevenard Island population

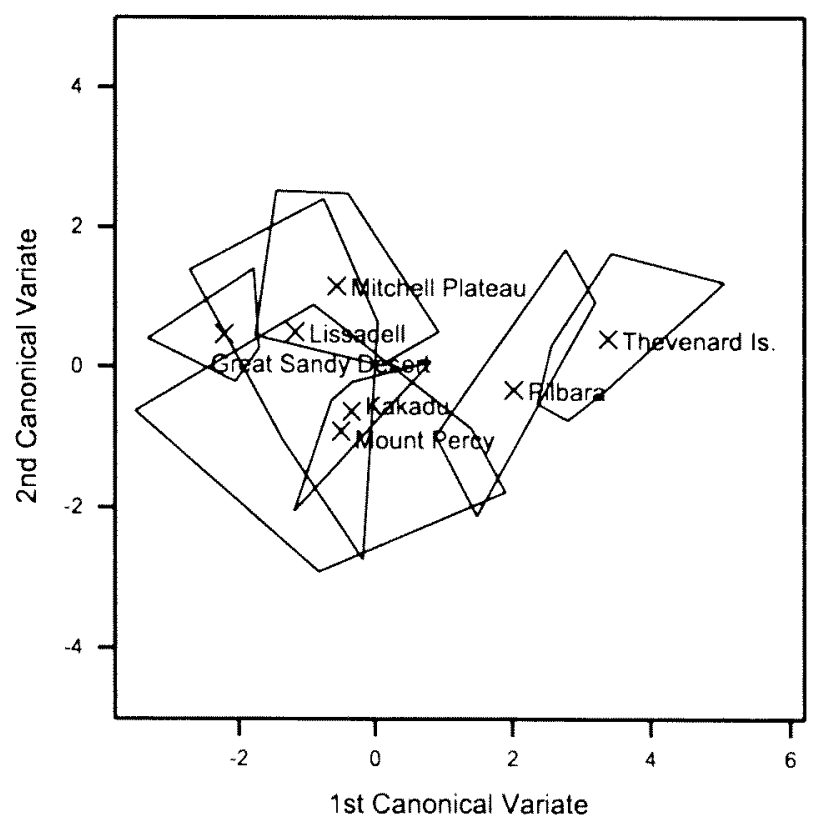

Figure 6 Plot on the first two canonical variates, using skull variables, of seven L. lakedownensis populations showing group centroids and polygons enclosing the range of individals. 


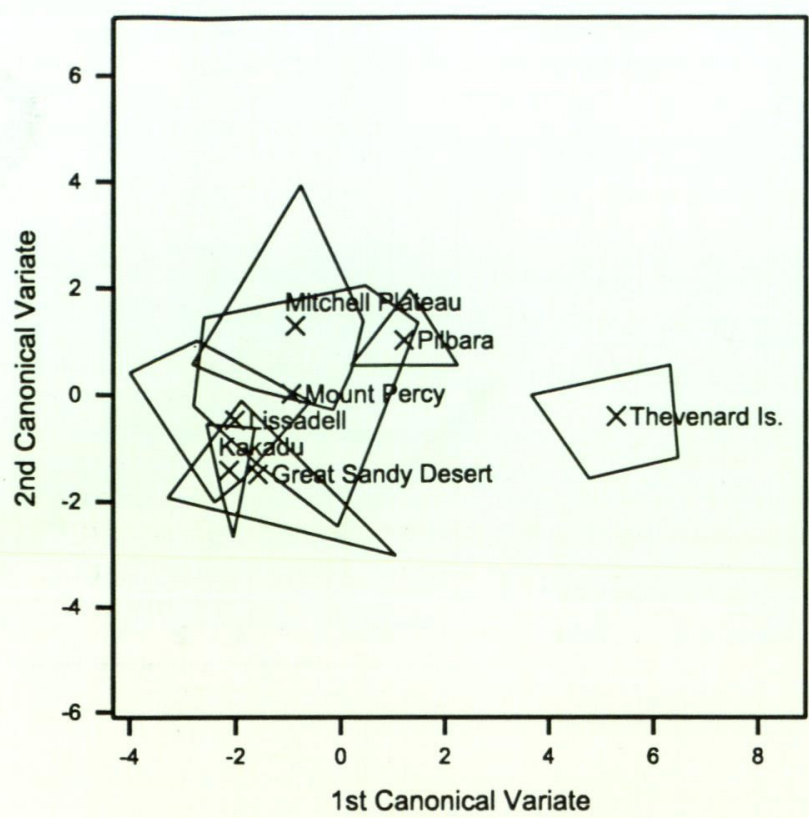

Figure 7 Plot on the first two canonical variates, using external variables, of seven L. lakedownensis populations showing group centroids and polygons enclosing the range of individals. from the others on the first canonical variate (Figure 7 ). This axis accounts for $85 \%$ of the between-group variation and is positively correlated with all measures (Table 5), this reflects the large size of the Thevenard Island animals, particularly in regard to the length of the tail-vent and pes.

\section{Morphological variation in L. lakedownensis and L. forresti}

\section{Skull and teeth}

Differences in skull and tooth morphology of L. lakedownensis and L. forresti are summarised in Table 6. Figures $8 \mathrm{a}-\mathrm{c}$, are dorsal, ventral and lateral photographs of skulls of L. lakedownensis, the smaller skull, M16906 and L. forresti, the larger skull, M6352. Both species appear quite variable, with especially marked geographic variation in the former species. The molar structure of both species is very similar with variation in the relative size of individual cusps and teeth rather than in their overall shape. From the canonical variate analysis, the variables $B D, B L, M^{1} L, M^{1} M^{3} L, C I L$ were the most significant in diagnosing the two species; these

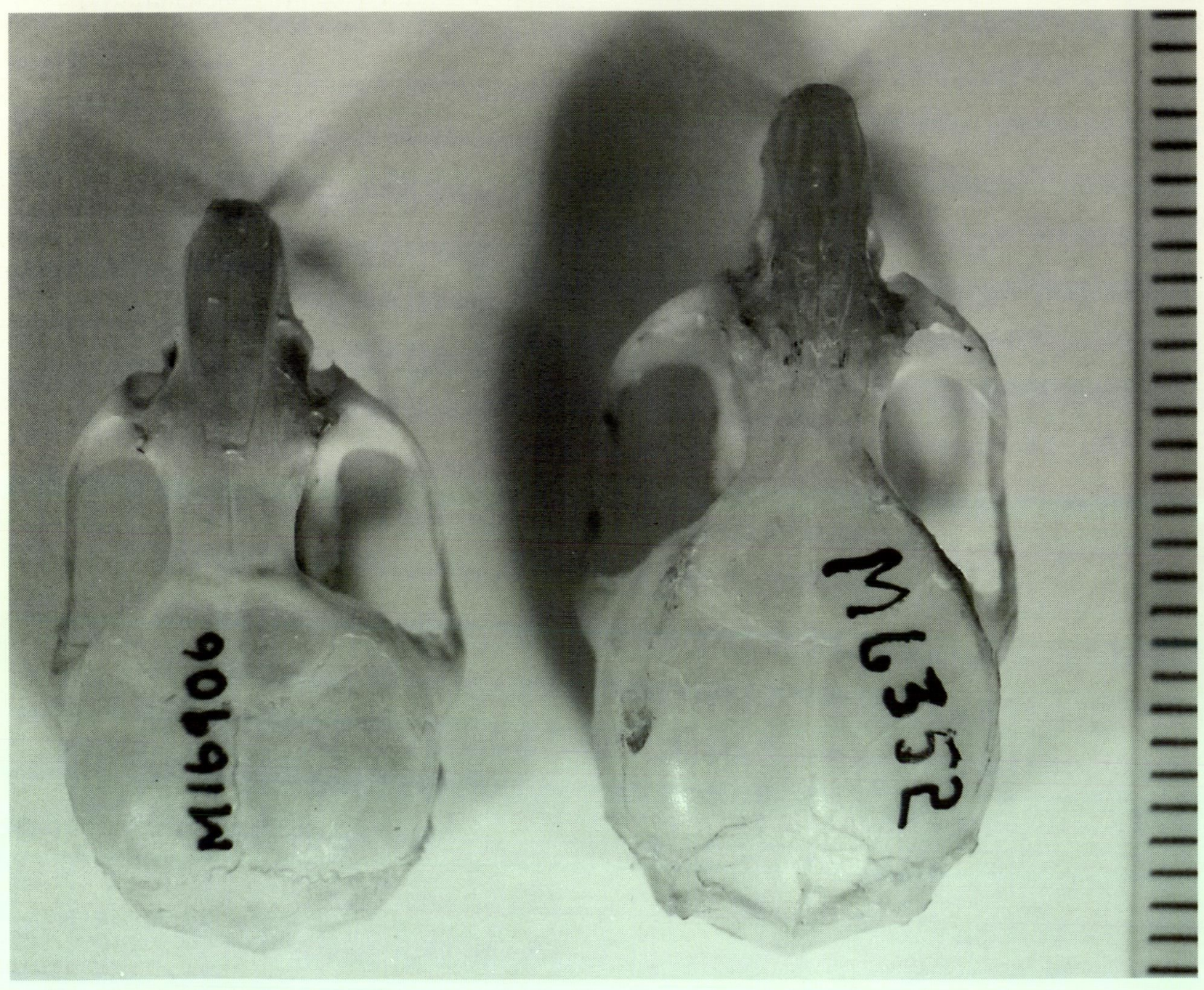

Figure 8a Dorsal view of L. lakedownensis, left, M16906 and L. forrestii, right, M6352. 


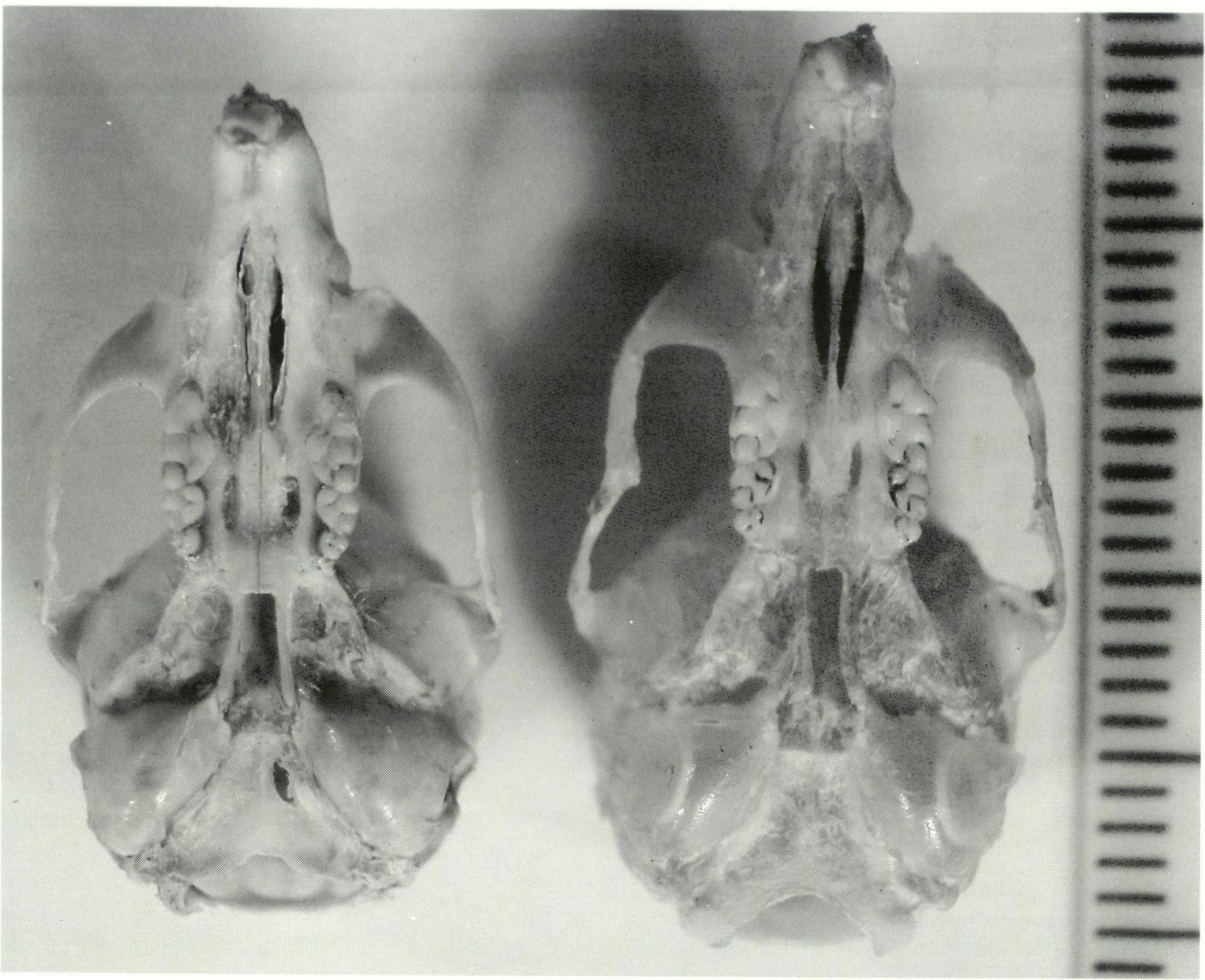

Figure 8b Ventral view of L. lakedownensis, left, M16906 and L. forrestii, right, M6352.

Figure 8c Lateral view of L. lakedownensis, below, M16906 and L. forrestii, above, M6352.

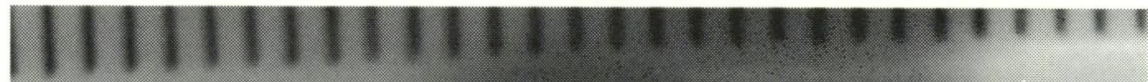


Table 6 Skull character differences between $L$. lakedownensis and $L$ forresti.

\begin{tabular}{ll}
\hline L. lakedownensis & L.forresti \\
\hline Upper incisor sometimes proodont & Upper incisor not proodont \\
Rostrum shorter, broader & Rostrum longer, narrower \\
Braincase "square" dorsally & Braincase "round" dorsally \\
Braincase shallower & Braincase deeper \\
Basicranium shorter (except for Thevenard Island animals) & Basicranium longer \\
Occipital surface of skull relatively flat, & Occipital surface of skull with distinct bulge in \\
$\quad$ with weak nuchal crest & supracoccipital region, nuchal crest well-developed \\
Nasal bone stops short of incisor & Nasal bone usually overlaps incisor \\
Bullae wider, longer, flatter & Bullae shorter, narrower, more inflated \\
$M^{1} L$ generally longer & $\mathrm{M}^{1} \mathrm{~L}$ generally shorter \\
$\mathrm{M}^{1}$ anterior cingulum long & $\mathrm{M}^{1}$ anterior cingulum short \\
$\mathrm{M}^{2}$ shorter relative to $\mathrm{M}^{1}$ & $\mathrm{M}^{2}$ longer relative to $\mathrm{M}^{1}$ \\
$\mathrm{M}_{1}$ longer & $\mathrm{M}_{1}$ shorter \\
Dentary angular process large & Dentary angular process finer \\
Condyle to tip of incisor generally shorter & Condyle to tip of incisor generally longer \\
\hline
\end{tabular}

are listed as distinguishing characters in Table 6. The two species differ in several cranial and dental charcteristics (Tables 6 and 7). One particularly diagnostic feature is the relative length of $\mathrm{M}^{1}$ to $\mathrm{M}^{2}$ $\left(\mathrm{M}^{1}\right.$ is relatively longer in $L$. lakedownensis). This reflects the relatively greater development of the $\mathrm{M}^{1}$ anterior cingular cuspule of L. lakedownensis, which approximates cusp $t 1$ in bulk in this species but is much smaller than $\mathrm{t} 1$ in $L$. forresti. This difference is reflected in a different overall crown outline for the $\mathrm{M}^{1}$, with a strongly L-shaped anterolingual inflection in $L$. lakedownensis and a more gently concave inflection in $L$. forresti. Variation in cingular morphology is also observed within $L$. lakedownensis. In Kimberley specimens of L.lakedownensis and in L. forresti the anterior cingulum extends posteriorly around the lingual face of cusp t1. In contrast, in Pilbara and Thevenard Island specimens, the cingulum terminates on the anterior face of cusp $t 1$.

Across the range of L. lakedownensis the incisive foramina only rarely widen posteriorly (Watts,
1976), rather than narrowing as is usual in $L$. forresti and there is only rarely a notch on the upper incisor (Grahame Medlin, pers comm.). No notches on the incisor have been observed in L. forresti.

The skull morphology of L. lakedownensis is variable across its geographic range, with the upper incisor usually proodontic in Kimberley populations and only occasionally in others; the Pilbara and Thevenard Island animals have larger skull, dental and dentary characters than other populations; and the accessory cusp in the Thevenard Island animals is not as elongated as in other groups.

\section{Externals measurements}

Mean values of external characters in $L$. forresti are larger than those of all L. lakedownensis populations except Thevenard Island, where the animals approach the size of L. forresti (Appendix 3). An exception is mean ear length which distinguishes the two species absolutely. Pes of $L$. forresti are not significantly wider than L. lakedownensis, contrary to

Table 7 Table of means and ratios of $\mathrm{M}^{1}$ and $\mathrm{M}^{2}$ for adult male and female $L$. forresti and $L$. lakedownensis.

\begin{tabular}{lccccccc}
\hline & \multicolumn{3}{c}{ L. forresti } & & \multicolumn{3}{c}{ L. lakedownesis } \\
\cline { 2 - 5 } & $\mathbf{M}^{2} \mathbf{L}$ & $\mathbf{M}^{\mathbf{1}} \mathbf{L}$ & $\% \mathbf{M}^{2} / \mathbf{M}^{\mathbf{1}}$ & & $\mathbf{M}^{2} \mathbf{L}$ & $\mathbf{M}^{\mathbf{1}} \mathbf{L}$ & $\% \mathbf{M}^{2} / \mathbf{M}^{\mathbf{1}}$ \\
\hline Male Total & 1.35 & 2.24 & $60.3 \%$ & & 1.19 & 2.40 & $49.6 \%$ \\
Female Total & 1.40 & 2.20 & $63.6 \%$ & & 1.23 & 2.40 & $51.3 \%$ \\
Pilbara male & & & & 1.33 & 2.48 & $53.6 \%$ \\
Pilbara female & & & & 1.29 & 2.53 & $50.1 \%$ \\
Thevenard male & & & & 1.28 & 2.49 & $51.4 \%$ \\
Thevenard female & & & & 1.26 & 2.43 & $51.9 \%$ \\
Kimberley male & & & & 1.15 & 2.38 & $48 \%$ \\
Kimberley female & & & & 1.21 & 2.37 & $51 \%$ \\
Queensland female & & & & 0.82 & 2.47 & $46 \%$ \\
\hline
\end{tabular}


Watts (1976). Mean tail length relative to head and body length for L. lakedownensis ranges from $72 \%$ in males in the Northern Territory to $91 \%$ for males in the Pilbara and $99 \%$ for females in Thevenard. For $L$. forrest $i$ the mean values are $81 \%$ for females and $83 \%$ for males.

\section{Pelage and footpads}

Unlike L. forresti, L. lakedownensis is variable in pelage colour, with the palest being Queensland specimens and the darkest being from the Pilbara. $L$. forrest $i$ is more rufous dorsally and it has a pure white belly. L. lakedownensis is more mouse-like (greyish) in colour overall, with only Queensland and Great Sandy Desert specimens having a white to cream coloured belly, though never as starkly white as in L.forresti. The tails of L. forresti are generally hairier in appearance than those of L. lakedownensis, probably because the hairs are longer in $L$. forresti rather than being more numerous per scale. In general the tail of both species is bicoloured, with the upper part similar in colour to the dorsal fur and the lower part paler, similar in colour to the ventrum fur. Tails of L. lakedownensis range from only slightly bicoloured to distinctly bicoloured. In general the pes of both species are cream to white, with the hair on the feet usually the same colour as the ventral hair.

The pattern of pedal variation in the two species is the same although there is some individual variation. For example, the lower pad under the hallux, (the post hallucal pad) is sometimes missing or very indistinct in both species.

Overall, L. forresti has a more chestnut dorsal appearance and stark white ventrally. Dorsally, base $50 \%$ is dark grey with upper half, buff; ventrally, snow white. Tail with almost no bicolour and some tails hairier than others.

The pelage of L. lakedownensis varies across its geographic range. In the Kimberley, at the Mitchell Plateau the dorsum is grey with chestnut tips; the ventrum is grey with chestnut tips; the tail is bicoloured, pale below, brownish above; and the footpads are tiny, sometimes with one indistinct. At Mt Percy, the dorsal fur is chestnut tipped (50\% to $33 \%$ of length) over grey; the ventrum is cream; the tail is slightly bicoloured, brown above, cream below; and the footpads are the same as for the Mitchell Plateau population. At Lissadell the dorsal fur is chestnut tipped ( $33 \%$ of length) over grey; the ventrum is white to creamy with a little grey; the tail is slightly bicoloured to unicoloured; and the footpads are the same as for Mitchell Plateau specimens.

In the Pilbara region, the Thevenard Island specimens have a dorsum that is either chestnut $(33 \%)$ over brown or all chestnut; the ventrum is either brown with the tip cream or is totally cream; the tail is unicoloured or weakly bicoloured; the footpads are similar in pattern to other L. lakedownensis and variable. At Tom Price the dorsum is chestnut (33\%) over grey but with an additional grey tip; the ventrum is grey/cream; the tail is bicoloured, dark grey above, paler below. At Millstream the dorsum is $25 \%$ chestnut over dark grey; the ventrum is chestnut/grey or mainly cream with some grey; the tail is bicoloured, grey above, pale below. At Newman the dorsum is $25 \%$ chestnut over dark grey; the ventrum is chestnut/ grey; the tail is bicoloured as for dorsal and ventral fur. At West Angeles the dorsum 25\% chestnut over grey; the ventrum is chestnut/grey; the tail is bicoloured as for the dorsal and ventral fur.

In the Great Sandy Desert the dorsum is almost entirely chestnut; the ventrum almost entirely white; the tail is bicoloured, cream below and pale brown above; the footpads are very small - the post hallucal pad is indistinct.

In Queensland specimens the dorsum ranges between all chestnut to chestnut $(50 \%)$ over dark grey, through to chestnut $(50 \%)$ over pale grey; the ventrum ranges from all white to cream; the tail ranges from slightly bicoloured to distinctly bicoloured; and the footpads range from a small indistinct post hallucal pad to distinct post hallucal pad.

In the Northern Territory the dorsum ranges from chestnut $(50 \%)$ over dark grey with to $(50 \%)$ chestnut over pale grey; the ventrum ranges from white $(66 \%)$ over dark grey to white $(66 \%)$ over pale grey; the tail ranges from slightly bicoloured to distinctly bicoloured; and the footpads range from small indistinct post hallucal pad to distinct post hallucal pad.

\section{DISCUSSION}

Prior to 1997, only two specimens of Leggadina had been collected from the Pilbara region. However, in the past five years, various faunal surveys by environmental consultants and government scientists have seen some thirty additional specimens collected and lodged in the Western Australian Museum, with other individuals marked and released. It appears, therefore, that L. lakedownensis is more widespread and common than previously thought, and perhaps undergoes periods of both population increase and scarcity (Stuart Anstee, pers.com).

A previous study of genetic variation within Leggadina (Baverstock et al. 1976) examined the karyotype and variation at sixteen allozyme loci, with L. lakedownensis represented by only three specimens from Queensland. Using a more geographically diverse range of specimens and many more allozyme loci, this study confirms that the level of genetic differentiation between L. lakedownensis and L. forresti is substantial and falls 
well beyond the range of intra-specific mammalian variation (Nei 1987). Furthermore, the mean heterozygosity within each of the populations accords well with other mammalian species (Nei 1987). The single specimen sampled from the Thevenard Island population was homozygous at all loci; this may reflect genetic drift in an isolate or it may be due to sampling error.

This study indicates that genetic differentiation, as measured by 44 nuclear loci, is minimal between populations of L. lakedownensis across its range. Moro et al. (1998) reported mtDNA differences between populations of L. lakedownensis and noted that the Pilbara and Thevenard Island populations showed the greatest divergence from the other regions. This dichotomy is not supported by the allozyme data, which instead group all three Western Australian populations together to the exclusion of those to the east, and suggest that the Queensland population (albeit represented by a single specimen) is the most differentiated. The Pilbara/Thevenard Island animals are considerably larger than all others; indeed, the Thevenard Island animals in particular are so large that some have suggested that they may represent either a distinct species or a geographic outlier of $L$. forresti. Neither of these suggestions are supported by any of the three data sets now available. Of course, it might still be argued that the Pilbara/Thevenard Island populations warrant recognition as a distinct subspecies, but the overlap in sizes between the Pilbara and Mount Percy populations, coupled with the lack of any allozyme differentiation in Western Australia, leads us to conclude otherwise.

The skulls of L. lakedownensis and L. forresti can be distinguished using the ratio of $\mathrm{M}^{2} \mathrm{~L} / \mathrm{M}^{1} \mathrm{~L}$ and on the degree of elongation of the anterior cingulum on $\mathrm{M}^{1}$ in L. lakedownensis. Externally, L. forresti can easily be distinguished from L. lakedownensis by its more rufous dorsal and pure white venter. L. forresti also has longer ears than any population of L. lakedownensis.

The skulls of L. lakedownensis morphologically are quite variable including features that might normally be expected to distinguish murine species (e.g. incisor orientation). However, this species has the largest geographic distribution of the two, and therefore experiences a wide variety of habitats and climates. The Thevenard Island population has a much larger body size than the other populations. Pelage pattern also shows marked differences between populations and, together with body size, can be used to confidently assign animals into their appropriate geographic region. L. forrest $i$ has a more discrete distribution in central Australia, and this appears to be reflected in the morphologically more homogenous nature of this species.

According to Reid and Morton (1995), the distribution of L. forresti extends further into Queensland and New South Wales than has been surveyed herein. Accordingly, we may not have fully characterized the genetic and morphological diversity present in this species. Based on present knowledge of extant populations, the geographic distributions of the two Leggadina species are clearly disjunct, permitting species identification in the field to be predicted from an animal's geographic location. Fortunately, sufficient differences in their external morphology are available to make this a method of convenience rather than one of need.

In summary, the morphological and allozyme data presented herein demonstrate that the genus Leggadina comprises two allopatric species, $L$. lakedownensis and $L$. forresti. These can be diagnosed using both morphological and genetic criteria. Of the two, L. lakedownensis displays more geographic variation than $L$. forresti, but this variation is nevertheless insufficient to warrant subspecific status for any regional populations.

\section{ACKNOWLEDGEMENTS}

The authors would like to thank Cath Kemper, Paul Horner and Steve Van Dyck who kindly loaned specimens from the South Australian Museum, the Northern Territory Museum and the Queensland Museum respectively. Thanks to Ken Aplin for morphometric advice and to Grahame Medlin who shared some morphometric information. Thanks to Mark Salotti for Figure 2, modified with permission, from Watts (1976).

\section{REFERENCES}

Adams, M., Baverstock, P.R., Watts, C.H.S. and Reardon, T. (1987). Electrophoretic resolution of species boundaries in Australian Microchiroptera: I. Eptesicus (Chiroptera: Vespertilionidae). Australian Journal of Biological Science 40: 143-162

Baverstock, P.R., Hogarth, J.T., Cole, S. and Covacevich, J. (1976). Biochemical and karyotypic evidence for the specific status of the rodent Leggadina lakedownensis Watts. Transactions of the Royal Society of South Australia 100: 109-112 Cavalli-Sforza, L. L and Edwards, A.W.F. (1967). Phylogenetic analysis: models and estimation procedures. Evolution 21: 550570

Genstat (2000). Genstat for Windows. Release 4.2. Fifth Edition. VSN International Ltd., Oxford

Gower, J.C. (1966). Some distance properties of latent root and vector methods used in multivariate analysis. Biometrika 53: 325-338

Kumar, S., Tamura, K., Jakobsen, I.B. and Nei, M. MEGA2: Molecular Evolutionary Genetics Analysis software, Bioinformatics (submitted)

Moro, D., Campbell, N.J.H., Elphinstone, M.S. and Baverstock, P.R. (1998). The Thevenard Island Mouse: historic and conservation implications from 
mitochondrial DNA sequence-variation. Pacific Conservation Biology 4: 282-288

Nei, M. (1978). Estimation of average heterozygosity and genetic distance from a small number of individuals. Genetics 89: 583-590

Nei, M. (1987). Molecular evolutionary genetics. Columbia University Press, New York.

Reid, J.W.R. and Morton, S.R. (1995) in R. Strahan (ed.), The Mammals of Australia: 555-556. Australian Museum/ Reed Books, Chatswood.

Richardson, B.J., Baverstock, P.R. and Adams, M. (1986). Allozyme electrophoresis: a handbook for animal systematics and population studies. Academic Press, Sydney.
Saitou, N. and Nei, M. (1987). The neighbor-joining method: A new method for reconstructing phylogenetic trees. Molecular Biology and Evolution 4: 406-425

Swofford, D.L. and Selander, R.B. (1989). BIOSYS-1: a computer program for the analysis of allelic variation in population genetics and biochemical systematics. Release 1.7. Illinois Natural History Survey, Champaign.

Watts, C.H.S. (1976). Leggadina lakedownensis, A new species of murid Rodent from North Queensland. Transactions of the Royal Society of South Australia 100: 105-108

Watts, C.H.S. and Aslin, H.J. (1981). The rodents of Australia. Angus and Robertson, Sydney.

Manuscript received 1 July 2002; accepted 22 November 2002 
Appendix 1 Collection data for specimens used in genetic analyses. Prefixes for registration numbers are SAM - South Australian Museum; WAM - Western Australian Museum; NTM - Museum of the Northern Territory; JM - Queensland Museum; ABTC - Australian Biological Tissues Collection

\section{L. forresti}

Northern Territory

MacDonnell Ranges, $23^{\circ} 26^{\prime} \mathrm{S}, 134^{\circ} 44^{\prime} \mathrm{E}, \mathrm{ABTC} 24040$

\section{South Australia}

Yelpawaralinna Water, $27^{\circ} 05^{\prime} \mathrm{S}, 1^{\circ} 8^{\circ} 41^{\prime} \mathrm{E}, \mathrm{SAM}$ M17585; Koonchera Waterhole, $23^{\circ} 43^{\prime} \mathrm{S}, 139^{\circ} 31^{\prime} \mathrm{E}, \mathrm{SAM}$ M17570; Dulkaninna - $28^{\circ} 59^{\prime} \mathrm{S}, 138^{\circ} 33^{\prime} \mathrm{E}, \mathrm{SAM}$ M17835, $28^{\circ} 57 \mathrm{~S}$, $138^{\circ} 38^{\prime} \mathrm{E}$, SAM M17834; Dalarinna Hill, $2^{\circ} 41^{\prime} \mathrm{S}, 138^{\circ} 41^{\prime} \mathrm{E}$, SAM M17847; North Olary Plains-32 $02^{\prime}$ 'S, $140^{\circ} 54^{\prime} \mathrm{E}$, SAM M18869, $30^{\circ} 28^{\prime} \mathrm{S}, 140^{\circ} 57^{\prime} \mathrm{E}$, SAM M18876; Todmorden Station, $27^{\circ} 22^{\prime} S, 134^{\circ} 31^{\prime} \mathrm{E}, \mathrm{SAM}$ M19214; Nilpinna Station, $28^{\circ} 13^{\prime} \mathrm{S}, 135^{\circ} 25^{\prime} \mathrm{E}$, SAM M19251; Pitpalyatjara, $26^{\circ} 10^{\prime} \mathrm{S}, 129^{\circ} 09^{\prime} \mathrm{E}$, SAM M18343-4

\section{L. lakedownensis}

\section{Northern Territory}

Litchfield N.P., $13^{\circ} 29^{\prime}$ S, $130^{\circ} 42^{\prime}$ E, NTM U4198; Bradshaw Stn, $15^{\circ} 23^{\prime} \mathrm{S}, 130^{\circ} 09^{\prime} \mathrm{E}$, ABTC30310; Gregory Creek, $15^{\circ} 19^{\prime} \mathrm{S}, 131^{\circ} 08^{\prime} \mathrm{E}$ NTM U386; Kakadu, $12^{\circ} 40^{\prime} \mathrm{S}, 132^{\circ} 50^{\prime} \mathrm{E}$, ABTC28413-4

\section{Western Australia}

Kimberley

Mitchell Plateau - $14^{\circ} 52^{\prime} 05^{\prime \prime} S, 125^{\circ} 50^{\prime} 45^{\prime \prime} \mathrm{E}$, WAM M21786, 14 $49^{\prime} 15^{\prime \prime S}, 125^{\circ} 50^{\prime} 15^{\prime \prime} \mathrm{E}$, WAM M21762-3;

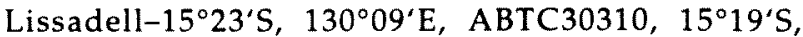
$130^{\circ} 08^{\prime} \mathrm{E}$, NTM U386

\section{Pilbara}

Millstream - $21^{\circ} 24^{\prime} 49^{\prime \prime} \mathrm{S}, 117^{\circ} 09^{\prime} 43^{\prime \prime} \mathrm{E}$, WAM M47733, $21^{\circ} 19^{\prime} 48^{\prime \prime} \mathrm{S}, 117^{\circ} 11^{\prime} 20^{\prime \prime} \mathrm{E}$, WAM M47720-1, $21^{\circ} 35^{\prime} \mathrm{S}$, $117^{\circ} 04^{\prime} \mathrm{E}$, ABTC10610; Mt Tom Price, $22^{\circ} 44^{\prime} \mathrm{S}, 117^{\circ} 47^{\prime} \mathrm{E}$, WAM M47829; Newman, $22^{\circ} 55^{\prime} \mathrm{S}, 118^{\circ} 43^{\prime} \mathrm{E}$, WAM M47912; Thevenard Island, $21^{\circ} 28^{\prime} \mathrm{S}, 115^{\circ} 00^{\prime} \mathrm{E}, \mathrm{ABTC} 10622$

Queensland

Paluma, $19^{\circ} 00^{\prime} \mathrm{S}, 146^{\circ} 01^{\prime} \mathrm{E}$, JM10863 
Appendix 2 Collection Data for specimens used in morphological study. Locality, geographic coordinates, sex (M male, F female) and registration number. Prefixes for registration numbers are as in Appendix 1. An asterisk beside the Museum number denotes this specimen also used in genetic analysis.

\section{L. forresti}

Northern Territory

MacDonald, 22 $25^{\prime} 36^{\prime \prime S}, 135^{\circ} 07^{\prime} 36^{\prime \prime}$ E, f, NTM U2958; Oodnadatta, $24^{\circ} 48^{\prime} 00^{\prime \prime} \mathrm{S}, 135^{\circ} 22^{\prime} 36^{\prime \prime} \mathrm{E}, \mathrm{m}$, NTM U6352; Coorabulka, $23^{\circ} 44^{\prime} 48^{\prime \prime} \mathrm{S}, 140^{\circ} 18^{\prime} 00^{\prime \prime} \mathrm{E}$, f, NTM U9688; Yuendumu, $22^{\circ} 15^{\prime} 00^{\prime \prime} \mathrm{S}, 131^{\circ} 48^{\prime} 00^{\prime \prime} \mathrm{E}, 2 \mathrm{f}$, NTM U13628-9, f,

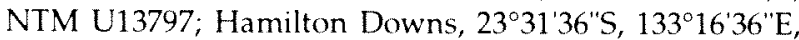
m, NTM U 13632

Queensland

Birdsville , 22023'48"S, $139^{\circ} 38^{\prime} 48^{\prime \prime} \mathrm{E}, 2 \mathrm{~m}$, NTM U6350-1

South Australia

Innamincka, $27^{\circ} 44^{\prime} 48^{\prime \prime} \mathrm{S}, 140^{\circ} 46^{\prime} 36^{\prime \prime} \mathrm{E}, \mathrm{m}, \mathrm{SAM} \mathrm{M} 10170$ Embarka, 27 $43^{\prime} 36^{\prime \prime} \mathrm{S}, 140^{\circ} 08^{\prime} 48^{\prime \prime} \mathrm{E}$, m, SAM M11476; Ucatunna Hill, $27^{\circ} 24^{\circ} 02^{\prime \prime} \mathrm{S}, 135^{\circ} 52^{\prime \prime} 49^{\prime \prime}$, m, SAM M18514; Unducarra Hill, $26^{\circ} 28^{\prime} 32^{\prime \prime} \mathrm{S}, 134^{\circ} 19^{\prime} 53^{\prime \prime} \mathrm{E}$, f, SAM M18545; Memory Bore, $26^{\circ} 42^{\circ} 06^{\prime \prime} \mathrm{S}, 135^{\circ} 30^{\prime} 00^{\prime \prime} \mathrm{E}$, f. SAM M18563; Four Hills Trig, $28^{\circ} 30^{\prime} 00^{\prime \prime} \mathrm{S}, 136^{\circ} 30^{\circ} 00^{\prime \prime} \mathrm{E}, \mathrm{m}$, SAM M18710; Abertachna Well, 29 $43^{\prime} 12^{\prime \prime} S, 137^{\circ} 20^{\prime} 48^{\prime \prime} \mathrm{E}, \mathrm{m}$, SAM M18808; Emerald Spring, $29^{\circ} 23^{\prime} 00^{\prime \prime} \mathrm{S}, 137^{\circ} 08^{\prime} 48^{\prime \prime} \mathrm{E}, \mathrm{m}$, SAM M18816; Starvation Dam, 30'27'47'S, $140^{\circ} 56^{\prime} 48^{\prime \prime} \mathrm{E}$, m, SAM M18876; McIntyre Bore, 30²5'57'S, 140 ${ }^{\circ} 58^{\prime} 26^{\prime \prime} \mathrm{E}$ m, SAM M18882

Western Australia

SW Mann Range, 26 $18^{\circ} 00^{\prime \prime} \mathrm{S}, 128^{\circ} 52^{\prime} 36^{\prime \prime} \mathrm{E}, 2 \mathrm{f}$, SAM M6344-5; Bell Rock, $26^{\circ} 18^{\prime} 00^{\prime \prime} \mathrm{S}, 128^{\circ} 52^{\prime} 36^{\prime \prime} \mathrm{E}, 2 \mathrm{f}$, SAM M6347, SAM M6349

New South Wales

Fowlers Gap, $31^{\circ} 00^{\prime} 00^{\prime \prime} \mathrm{S}, 141^{\circ} 42^{\prime} 00^{\prime \prime} \mathrm{E}, \mathrm{m}$, SAM M13633

\section{L. lakedownensis}

Western Australia

Kimberley

Lissadell - 16 ${ }^{\circ} 44^{\prime} 00^{\prime \prime} \mathrm{S}, 128^{\circ} 26^{\prime} 36^{\prime \prime} \mathrm{E}, 4 \mathrm{~m}$, WAM M16893, WAM16869, WAM M19278-9, f, WAM M16870; $16^{\circ} 40^{\prime} 00^{\prime \prime} \mathrm{S}, 128^{\circ} 23^{\prime} 13^{\prime \prime} \mathrm{E}, 3 \mathrm{~m}$, WAM M16872, WAM M16874, WAM M16900; $16^{\circ} 44^{\circ} 00^{\prime \prime} \mathrm{S}, 128^{\circ} 26^{\prime} 36^{\prime \prime} \mathrm{E}, \mathrm{m}$, WAM M16893; $16^{\circ} 32^{\prime} 51^{\prime \prime} \mathrm{S}, 128^{\circ} 33^{\prime} 30^{\prime \prime} \mathrm{E}, \mathrm{m}$, WAM M18833; $17^{\circ} 37^{\prime} 00^{\prime \prime} \mathrm{S}, 124^{\circ} 52^{\prime} 19^{\prime \prime} \mathrm{E}, 3 \mathrm{~m}$, WAM M16904-6; Mt Percy- $17^{\circ} 35^{\prime} 54^{\prime \prime} \mathrm{S}, 124^{\circ} 54^{\prime} 06^{\prime \prime}$, 2f, WAM M16919-20; $17^{\circ} 41^{\prime 32}$ "S, $124^{\circ} 56^{\prime} 03^{\prime \prime} \mathrm{E}, \mathrm{m}$, WAM M16944, f, WAM M16945; $17^{\circ} 40^{\prime} 23^{\prime \prime S}, 124^{\circ} 56^{\prime} 03^{\prime \prime} \mathrm{E}, 3 \mathrm{~m}$, WAM M16944, WAM M16950-1 2f, WAM M16945-6; 1704'23"S,

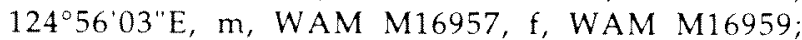
$17^{\circ} 37^{\prime} 00^{\prime \prime S}, 124^{\circ} 52^{\prime} 19^{\prime \prime} \mathrm{E}, 3 f$, WAM M16952, WAM M16962, WAM M16975; Barker Gorge- 17¹4'15"S,

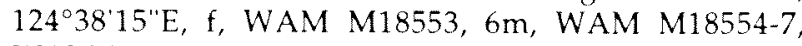
WAM M18559-60; Calder River, $16^{\circ} 19^{\prime} 00^{\prime \prime} \mathrm{S}, 124^{\circ} 58^{\prime} 00^{\prime \prime} \mathrm{E}$, f, WAM M17494; Mt North, $17^{\circ} 29^{\prime} 46^{\prime \prime} S, 124^{\circ} 45^{\circ} 05^{\prime \prime} E$, f,

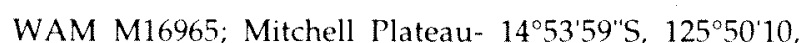
$\mathrm{m}$, WAM M15536, $14^{\circ} 35^{\prime} 15^{\prime \prime} \mathrm{S}, 1^{\circ} 5^{\circ} 45^{\circ} 30^{\prime \prime} \mathrm{E}, 2 \mathrm{f}$, WAM M18068-9, 2m, WAM M18070, WAM M18084; $14^{\circ} 47^{\prime} 59^{\prime \prime} \mathrm{S}$, $125^{\circ} 49^{\prime} 00^{\prime \prime} \mathrm{E}, \mathrm{m}$, WAM M18100; $14^{\circ} 52^{\prime} 05^{\prime \prime} \mathrm{S}, 125^{\circ} 50^{\prime} 45^{\prime \prime} \mathrm{E}, \mathrm{f}$,

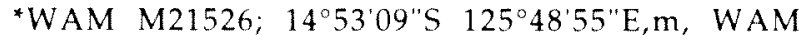
M21623; 14 49'14"S, $125^{\circ} 50^{\prime} 15^{\prime \prime} \mathrm{E}, \mathrm{m}$, *WAM M21762, 2f, WAM M21752, WAM M21767; $14^{\circ} 50^{\prime} 30^{\prime \prime} \mathrm{S}, 125^{\circ} 50^{\prime} 30^{\prime \prime} \mathrm{E}$,f, *WAM M21786; $14^{\circ} 52^{\prime} 19^{\prime \prime S}, 125^{\circ} 49^{\prime} 15^{\prime \prime} \mathrm{E}, \quad 3 f$, WAMMM22044, WAM M22090-1; Kununurra$15^{\circ} 47^{\prime} 30^{\prime \prime} \mathrm{S}, 128^{\circ} 45^{\prime} 30^{\prime \prime} \mathrm{E}, \mathrm{m}$, WAM M14857; $15^{\circ} 46^{\prime} 00^{\prime \prime} \mathrm{S}$, $128^{\circ} 44^{\prime} 00^{\prime \prime} \mathrm{E}, \mathrm{m}$, WAM M19644, f, WAM M19645; Bungle Bungle, $17^{\circ} 15^{\circ} 00^{\prime \prime} \mathrm{S}, 128^{\circ} 18^{\circ} 00^{\prime \prime} \mathrm{E}$, f, WAM M32657; Mclarty, $1^{\circ} 30^{\prime} 00^{\prime \prime} S, 123^{\circ} 30^{\circ} 00^{\prime \prime} \mathrm{E}$, m, WAM M19840; Gt Sandy Desert- $20^{\circ} 24^{\prime} 00^{\prime \prime} \mathrm{S}, 122^{\circ} 08^{\prime} 00^{\prime \prime} \mathrm{E}, 3 \mathrm{~m}$, WAM M2725, WAM M22725-6; 22 $33^{\prime} 00^{\prime \prime} S, 1^{\circ} 2^{\circ} 23^{\prime} 00^{\prime \prime} E$, m, WAM M22727; $20^{\circ} 20^{\prime} 59^{\prime \prime} \mathrm{S}, 127^{\circ} 26^{\circ} 00^{\prime \prime} \mathrm{E}, \mathrm{m}$, WAM M22728

Pilbara

Millstream- $21^{\circ} 35^{\prime} 59^{\prime \prime} \mathrm{S}, 117^{\circ} 04^{\prime} 00^{\prime \prime} \mathrm{E}$, f, WAM M27011;2m,

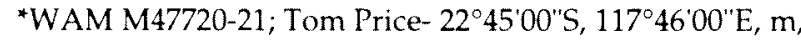
WAM M47326, $22^{\circ} 49^{\prime} 01^{\prime \prime} S, 115^{\circ} 46^{\prime} 53^{\prime \prime} \mathrm{E}$, f, WAM M47710, $22^{\circ} 48^{\prime} 48^{\prime \prime} S, 117^{\circ} 47^{\prime} 20^{\prime \prime} \mathrm{E}, 2 f$, WAM M47711-2; Chichester, $21^{\circ} 25^{\prime} 48^{\prime \prime} \mathrm{S}, 117^{\circ} 10^{\prime} 43^{\prime \prime} \mathrm{E}, \mathrm{m}$, *WAM M47733; Newman, $22^{\circ} 55^{\circ} 57^{\prime \prime} \mathrm{S}, 118^{\circ} 43^{\prime} 48^{\prime \prime} \mathrm{E}$, f, *WAM M47912; Westangeles-

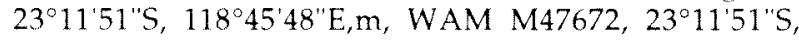
$118^{\circ} 44^{\circ} 08^{\prime \prime} \mathrm{E}$, f, WAM M47673

Thevenard Island

Thevenard Island, $21^{\circ} 28^{\prime} 00^{\prime \prime} \mathrm{S}, 115^{\circ} 00^{\circ} 00^{\prime \prime} \mathrm{E}, 9 \mathrm{~m}$, WAM M7402, WAM M7404-6, WAM M7408-10, WAM M7412, WAM M28921, 9f, WAM M7403, WAM M7411, WAM M21296, WAM M34163, WAM M47416-7, WAM M47434-5

\section{Queensland}

Lakeland, $15^{\circ} 50^{\circ} 48^{\prime \prime} \mathrm{S}, 144^{\circ} 50^{\prime} 48^{\prime \prime} \mathrm{E}, 2 \mathrm{~m}$, JM1024, JM2874, 2f, JM1293-4; Mapoon, $11^{\circ} 59^{\prime} 48^{\prime \prime} \mathrm{S}, 142^{\circ} 00^{\prime} 00^{\prime \prime} \mathrm{E}$, JM4030; Batavia, $12^{\circ} 09^{\prime} 00^{\prime \prime} \mathrm{S}, 141^{\circ} 54^{\prime} 00^{\prime \prime} \mathrm{E}$, JM4031; Stonexing, $12^{\circ} 23^{\prime} 48^{\prime \prime} \mathrm{S}, 142^{\circ} 00^{\circ} 00^{\prime \prime} \mathrm{E}, \mathrm{f}, \mathrm{JM} 4032$; Hillgrove, $19^{\circ} 38^{\prime} 48^{\prime \prime} \mathrm{S}$, $145^{\circ} 43^{\prime} 12^{\prime \prime} \mathrm{E}, \mathrm{m}, \mathrm{JM} 4954$; Hiddenvall, $19^{\circ} 00^{\circ} 00^{\prime \prime} \mathrm{S}$, $146^{\circ} 05^{\prime} 48^{\prime \prime} \mathrm{E}, \mathrm{f}, \mathrm{JM} 10863$; Undurra, $18^{\circ} 13^{\prime} 12^{\prime \prime} \mathrm{S}$, $144^{\circ} 34^{\prime} 12^{\prime \prime} \mathrm{E}$, f, JM11573; Rolleston, 2428 12"S, $148^{\circ} 38^{\circ} 48^{\prime \prime} \mathrm{E}, \mathrm{f}, \mathrm{JM} 11585$; Williams, $14^{\circ} 37^{\prime} 12^{\prime \prime} \mathrm{S}$ $144^{\circ} 06^{\prime} 00^{\prime \prime} \mathrm{E}, \mathrm{f}, \mathrm{JM} 17919$

\section{Northern Territory}

Pine Creek, $13^{\circ} 30^{\circ} 00^{\prime \prime} \mathrm{S}, 131^{\circ} 28^{\prime} 12^{\prime \prime} \mathrm{E}, \mathrm{f}, \mathrm{NTM} \mathrm{U} 2445$; Litchfield, $13^{\circ} 09^{\circ} 00^{\prime \prime} \mathrm{S}, 130^{\circ} 26^{\prime} 24^{\prime \prime} \mathrm{E}$, f, NTM U4198. $16^{\circ} 04^{\prime} 12^{\prime \prime} \mathrm{S}, 130^{\circ} 15^{\prime} 00^{\prime \prime} \mathrm{E}, \mathrm{m}, \mathrm{NTM}$ U4353; Mt Sanford, $16^{\circ} 35^{\prime 2} 24^{\prime \prime S}, 130^{\circ} 20^{\prime} 24^{\prime \prime} E$, m, NTM U4480; Kakadu$13^{\circ} 25^{\prime} 00^{\prime \prime} \mathrm{S}, 132^{\circ} 06^{\circ} 00^{\prime \prime} \mathrm{E}, \mathrm{f}$, WAM M43288, $13^{\circ} 29^{\prime} 59^{\prime \prime} \mathrm{S}$,

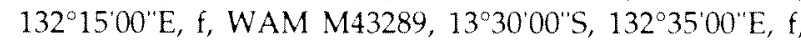
WAM M43290, $13^{\circ} 31^{\circ} 00^{\prime \prime} S, 132^{\circ} 27^{\circ} 00^{\prime \prime} \mathrm{E}, \mathrm{m}$, WAM M43291, $13^{\circ} 23^{\prime} 59^{\prime \prime} S, 132^{\circ} 16^{\circ} 00^{\prime \prime} \mathrm{E}, \mathrm{m}$, WAM M43292. 
Appendix 3 Summary statistics for twenty skull and six external variables in eight populations of Leggadina lakedownensis and in $L$. forresti. ( $F=$ female; $M=$ male)

\begin{tabular}{|c|c|c|c|c|c|c|c|c|c|c|c|c|c|c|c|c|c|c|c|}
\hline \multirow[t]{2}{*}{ Variable } & \multirow[t]{2}{*}{ Statistic } & \multicolumn{2}{|c|}{ Pilbara } & \multicolumn{2}{|c|}{$\begin{array}{l}\text { Thevenard } \\
\text { Island }\end{array}$} & \multicolumn{2}{|c|}{$\begin{array}{l}\text { Great Sandy } \\
\text { Desert }\end{array}$} & \multicolumn{2}{|c|}{$\begin{array}{l}\text { Mount } \\
\text { Percy }\end{array}$} & \multicolumn{2}{|c|}{$\begin{array}{l}\text { Mitchell } \\
\text { Plateau }\end{array}$} & \multicolumn{2}{|c|}{ Lissadell } & \multicolumn{2}{|c|}{ Kakadu } & \multicolumn{2}{|c|}{ Queensland } & \multicolumn{2}{|c|}{ L. forresti } \\
\hline & & $\mathrm{F}$ & $\mathrm{M}$ & F & M & F & $\mathrm{M}$ & $\mathrm{F}$ & M & $\mathrm{F}$ & M & $\mathrm{F}$ & $\mathrm{M}$ & $\mathrm{F}$ & M & $\mathrm{F}$ & M & F & $\mathrm{M}$ \\
\hline GL & $\begin{array}{r}n \\
\text { mean } \\
\mathrm{sd} \\
\min \\
\max \end{array}$ & $\begin{array}{c}3 \\
22.8 \\
1.00 \\
21.7 \\
23.6\end{array}$ & $\begin{array}{c}4 \\
23.6 \\
0.65 \\
22.8 \\
24.2\end{array}$ & $\begin{array}{c}5 \\
24.9 \\
1.30 \\
23.7 \\
27.1\end{array}$ & $\begin{array}{c}5 \\
23.4 \\
0.81 \\
22.0 \\
24.0\end{array}$ & $\begin{array}{c}4 \\
20.8 \\
0.95 \\
19.6 \\
21.8\end{array}$ & 0 & $\begin{array}{l}11 \\
21.7 \\
1.12 \\
19.5 \\
23.1\end{array}$ & $\begin{array}{l}10 \\
21.5 \\
1.07 \\
20.0 \\
23.5\end{array}$ & $\begin{array}{c}6 \\
21.8 \\
0.61 \\
21.1 \\
22.6\end{array}$ & $\begin{array}{c}9 \\
22.0 \\
0.59 \\
21.2 \\
22.9\end{array}$ & $\begin{array}{l}10 \\
21.8 \\
0.71 \\
20.8 \\
22.9\end{array}$ & $\begin{array}{c}3 \\
21.1 \\
0.40 \\
20.7 \\
21.5\end{array}$ & $\begin{array}{c}2 \\
22.2 \\
0.81 \\
21.6 \\
22.8\end{array}$ & $\begin{array}{c}3 \\
20.6 \\
0.26 \\
20.3 \\
20.8\end{array}$ & 0 & 0 & $\begin{array}{c}6 \\
24.2 \\
0.52 \\
23.3 \\
25.0\end{array}$ & $\begin{array}{c}9 \\
23.5 \\
0.79 \\
22.2 \\
24.7\end{array}$ \\
\hline $\mathrm{BD}$ & $\begin{array}{r}n \\
\text { mean } \\
\text { sd } \\
\min \\
\max \end{array}$ & $\begin{array}{l}3 \\
7.4 \\
0.29 \\
7.1 \\
7.7\end{array}$ & $\begin{array}{l}4 \\
7.4 \\
0.22 \\
7.2 \\
7.7\end{array}$ & $\begin{array}{l}5 \\
7.3 \\
0.34 \\
7.0 \\
7.9\end{array}$ & $\begin{array}{l}5 \\
7.3 \\
0.21 \\
7.0 \\
7.5\end{array}$ & $\begin{array}{l}4 \\
6.8 \\
0.24 \\
6.5 \\
7.0\end{array}$ & 0 & $\begin{array}{l}12 \\
7.0 \\
0.34 \\
6.5 \\
7.4\end{array}$ & $\begin{array}{l}10 \\
7.0 \\
0.28 \\
6.6 \\
7.7\end{array}$ & $\begin{array}{l}6 \\
7.1 \\
0.24 \\
6.7 \\
7.4\end{array}$ & $\begin{array}{l}9 \\
6.9 \\
0.24 \\
6.7 \\
7.4\end{array}$ & $\begin{array}{l}10 \\
7.1 \\
0.38 \\
6.7 \\
7.8\end{array}$ & $\begin{array}{l}3 \\
6.9 \\
0.16 \\
6.7 \\
7.0\end{array}$ & $\begin{array}{l}2 \\
7.2 \\
0.44 \\
6.9 \\
7.5\end{array}$ & $\begin{array}{l}3 \\
7.0 \\
0.17 \\
6.8 \\
7.1\end{array}$ & 0 & 0 & $\begin{array}{l}6 \\
7.6 \\
0.22 \\
7.2 \\
7.7\end{array}$ & $\begin{array}{l}9 \\
7.6 \\
0.37 \\
7.1 \\
8.1\end{array}$ \\
\hline IPW & $\begin{array}{r}\mathrm{n} \\
\text { mean } \\
\mathrm{sd} \\
\min \\
\max \end{array}$ & $\begin{array}{l}3 \\
8.2 \\
0.56 \\
7.8 \\
8.8\end{array}$ & $\begin{array}{l}3 \\
8.2 \\
0.48 \\
7.7 \\
8.6\end{array}$ & $\begin{array}{l}5 \\
8.9 \\
0.37 \\
8.2 \\
9.2\end{array}$ & $\begin{array}{l}5 \\
8.7 \\
0.43 \\
8.1 \\
9.3\end{array}$ & $\begin{array}{l}4 \\
7.0 \\
0.42 \\
6.4 \\
7.4\end{array}$ & 0 & $\begin{array}{l}11 \\
7.6 \\
0.42 \\
7.0 \\
8.5\end{array}$ & $\begin{array}{l}10 \\
7.6 \\
0.46 \\
6.7 \\
8.4\end{array}$ & $\begin{array}{l}6 \\
7.8 \\
0.40 \\
7.3 \\
8.5\end{array}$ & $\begin{array}{l}9 \\
8.0 \\
0.44 \\
7.0 \\
8.4\end{array}$ & $\begin{array}{l}10 \\
7.5 \\
0.49 \\
6.4 \\
8.1\end{array}$ & $\begin{array}{l}3 \\
7.6 \\
0.35 \\
7.3 \\
8.0\end{array}$ & $\begin{array}{l}2 \\
8.0 \\
0.36 \\
7.7 \\
8.2\end{array}$ & $\begin{array}{l}3 \\
7.8 \\
0.22 \\
7.7 \\
8.1\end{array}$ & 0 & 0 & $\begin{array}{l}6 \\
8.2 \\
0.45 \\
7.4 \\
8.7\end{array}$ & $\begin{array}{l}9 \\
8.0 \\
0.53 \\
7.3 \\
8.7\end{array}$ \\
\hline BW & $\begin{array}{r}n \\
\text { mean } \\
\text { sd } \\
\min \\
\max \end{array}$ & $\begin{array}{c}3 \\
10.8 \\
0.12 \\
10.7 \\
10.9\end{array}$ & $\begin{array}{c}4 \\
11.1 \\
0.36 \\
10.8 \\
11.6\end{array}$ & $\begin{array}{c}5 \\
11.3 \\
0.12 \\
11.1 \\
11.4\end{array}$ & $\begin{array}{c}5 \\
11.2 \\
0.35 \\
10.7 \\
11.6\end{array}$ & $\begin{array}{c}4 \\
10.2 \\
0.28 \\
9.8 \\
10.5\end{array}$ & 0 & $\begin{array}{l}11 \\
10.7 \\
0.49 \\
10.0 \\
11.5\end{array}$ & $\begin{array}{l}10 \\
10.6 \\
0.29 \\
10.2 \\
11.1\end{array}$ & $\begin{array}{c}6 \\
10.6 \\
0.26 \\
10.1 \\
10.9\end{array}$ & $\begin{array}{c}9 \\
10.6 \\
0.21 \\
10.3 \\
10.9\end{array}$ & $\begin{array}{l}10 \\
10.5 \\
0.31 \\
9.8 \\
10.8\end{array}$ & $\begin{array}{c}3 \\
10.3 \\
0.37 \\
10.0 \\
10.7\end{array}$ & $\begin{array}{c}2 \\
10.9 \\
0.46 \\
10.5 \\
11.2\end{array}$ & $\begin{array}{c}3 \\
10.5 \\
0.29 \\
10.3 \\
10.8\end{array}$ & 0 & 0 & $\begin{array}{c}7 \\
11.3 \\
0.24 \\
10.9 \\
11.6\end{array}$ & $\begin{array}{c}9 \\
11.0 \\
0.32 \\
10.5 \\
11.4\end{array}$ \\
\hline $\mathrm{ZW}$ & $\begin{array}{r}\mathrm{n} \\
\text { mean } \\
\mathrm{sd} \\
\min \\
\max \end{array}$ & $\begin{array}{c}3 \\
12.7 \\
0.82 \\
11.8 \\
13.3\end{array}$ & $\begin{array}{c}4 \\
12.9 \\
0.27 \\
12.6 \\
13.1\end{array}$ & $\begin{array}{c}5 \\
13.2 \\
0.31 \\
12.9 \\
13.6\end{array}$ & $\begin{array}{c}5 \\
12.7 \\
0.75 \\
11.6 \\
13.5\end{array}$ & $\begin{array}{c}4 \\
11.3 \\
0.59 \\
10.7 \\
12.0\end{array}$ & 0 & $\begin{array}{l}11 \\
12.1 \\
0.53 \\
11.2 \\
12.9\end{array}$ & $\begin{array}{l}10 \\
12.3 \\
0.68 \\
11.2 \\
13.4\end{array}$ & $\begin{array}{c}6 \\
11.7 \\
0.54 \\
10.8 \\
12.4\end{array}$ & $\begin{array}{c}9 \\
12.1 \\
0.34 \\
11.6 \\
12.6\end{array}$ & $\begin{array}{l}10 \\
11.7 \\
0.62 \\
10.4 \\
12.4\end{array}$ & $\begin{array}{c}3 \\
11.7 \\
0.27 \\
11.4 \\
12.0\end{array}$ & $\begin{array}{c}2 \\
12.5 \\
0.42 \\
12.2 \\
12.8\end{array}$ & $\begin{array}{c}3 \\
11.5 \\
0.34 \\
11.1 \\
11.7\end{array}$ & 0 & 0 & $\begin{array}{c}7 \\
12.9 \\
0.39 \\
12.2 \\
13.5\end{array}$ & $\begin{array}{c}9 \\
12.6 \\
0.76 \\
11.8 \\
13.8\end{array}$ \\
\hline IW & $\begin{array}{r}\mathrm{n} \\
\text { mean } \\
\mathrm{sd} \\
\min \\
\max \end{array}$ & $\begin{array}{l}3 \\
3.5 \\
0.22 \\
3.3 \\
3.8\end{array}$ & $\begin{array}{l}4 \\
3.8 \\
0.17 \\
3.6 \\
3.9\end{array}$ & $\begin{array}{l}5 \\
3.9 \\
0.14 \\
3.8 \\
4.1\end{array}$ & $\begin{array}{l}5 \\
3.9 \\
0.08 \\
3.8 \\
4.0\end{array}$ & $\begin{array}{l}4 \\
3.5 \\
0.17 \\
3.2 \\
3.6\end{array}$ & 0 & $\begin{array}{l}12 \\
3.4 \\
0.15 \\
3.2 \\
3.8\end{array}$ & $\begin{array}{l}10 \\
3.4 \\
0.14 \\
3.2 \\
3.7\end{array}$ & $\begin{array}{l}6 \\
3.5 \\
0.16 \\
3.4 \\
3.8\end{array}$ & $\begin{array}{l}9 \\
3.5 \\
0.18 \\
3.3 \\
3.8\end{array}$ & $\begin{array}{l}10 \\
3.4 \\
0.21 \\
3.1 \\
3.8\end{array}$ & $\begin{array}{l}3 \\
3.4 \\
0.10 \\
3.3 \\
3.5\end{array}$ & $\begin{array}{l}2 \\
3.5 \\
0.12 \\
3.4 \\
3.6\end{array}$ & $\begin{array}{l}3 \\
3.5 \\
0.02 \\
3.5 \\
3.5\end{array}$ & 0 & 0 & $\begin{array}{l}7 \\
3.7 \\
0.20 \\
3.5 \\
4.1\end{array}$ & $\begin{array}{l}9 \\
3.6 \\
0.21 \\
3.3 \\
3.9\end{array}$ \\
\hline NL & $\begin{array}{r}\mathrm{n} \\
\text { mean } \\
\mathrm{sd} \\
\min \\
\max \end{array}$ & $\begin{array}{l}3 \\
8.3 \\
0.93 \\
7.3 \\
9.1\end{array}$ & $\begin{array}{l}4 \\
8.3 \\
0.48 \\
7.7 \\
8.9\end{array}$ & $\begin{array}{l}5 \\
8.3 \\
1.02 \\
6.8 \\
9.4\end{array}$ & $\begin{array}{l}5 \\
7.8 \\
0.93 \\
6.3 \\
8.6\end{array}$ & $\begin{array}{l}4 \\
7.2 \\
0.44 \\
6.7 \\
7.6\end{array}$ & 0 & $\begin{array}{l}12 \\
7.6 \\
0.56 \\
6.8 \\
8.4\end{array}$ & $\begin{array}{l}10 \\
7.4 \\
0.42 \\
6.7 \\
8.1\end{array}$ & $\begin{array}{l}6 \\
7.7 \\
0.56 \\
6.7 \\
8.2\end{array}$ & $\begin{array}{l}9 \\
7.8 \\
0.49 \\
7.1 \\
8.5\end{array}$ & $\begin{array}{l}10 \\
7.7 \\
0.38 \\
6.7 \\
8.1\end{array}$ & $\begin{array}{l}3 \\
7.4 \\
0.20 \\
7.2 \\
7.6\end{array}$ & $\begin{array}{l}2 \\
8.0 \\
0.03 \\
8.0 \\
8.0\end{array}$ & $\begin{array}{l}3 \\
7.0 \\
0.13 \\
6.8 \\
7.1\end{array}$ & 0 & 0 & $\begin{array}{l}7 \\
8.1 \\
0.32 \\
7.5 \\
8.5\end{array}$ & $\begin{array}{l}9 \\
8.0 \\
0.39 \\
7.2 \\
8.4\end{array}$ \\
\hline
\end{tabular}




\begin{tabular}{|c|c|c|c|c|c|c|c|c|c|c|c|c|c|c|c|c|c|c|c|}
\hline NW & $\begin{array}{r}\mathrm{n} \\
\text { mean } \\
\mathrm{sd} \\
\min \\
\max \end{array}$ & $\begin{array}{l}3 \\
2.1 \\
0.19 \\
1.9 \\
2.2\end{array}$ & $\begin{array}{l}4 \\
2.1 \\
0.07 \\
2.0 \\
2.1 \\
\end{array}$ & $\begin{array}{l}5 \\
2.1 \\
0.19 \\
1.9 \\
2.4 \\
\end{array}$ & $\begin{array}{l}4 \\
2.0 \\
0.06 \\
2.0 \\
2.1 \\
\end{array}$ & $\begin{array}{l}4 \\
1.7 \\
0.09 \\
1.6 \\
1.8 \\
\end{array}$ & 0 & $\begin{array}{l}12 \\
1.9 \\
0.20 \\
1.4 \\
2.2 \\
\end{array}$ & $\begin{array}{l}10 \\
1.8 \\
0.24 \\
1.3 \\
2.0 \\
\end{array}$ & $\begin{array}{l}6 \\
1.9 \\
0.14 \\
1.8 \\
2.2\end{array}$ & $\begin{array}{l}9 \\
1.9 \\
0.14 \\
1.6 \\
2.0\end{array}$ & $\begin{array}{l}10 \\
1.8 \\
0.17 \\
1.5 \\
2.0\end{array}$ & $\begin{array}{l}3 \\
1.8 \\
0.17 \\
1.6 \\
1.9\end{array}$ & $\begin{array}{l}2 \\
1.8 \\
0.32 \\
1.6 \\
2.0\end{array}$ & $\begin{array}{l}3 \\
1.7 \\
0.22 \\
1.5 \\
1.9\end{array}$ & 0 & 0 & $\begin{array}{l}7 \\
2.0 \\
0.15 \\
1.9 \\
2.3 \\
\end{array}$ & $\begin{array}{l}8 \\
2.0 \\
0.16 \\
1.8 \\
2.3 \\
\end{array}$ \\
\hline MW & $\begin{array}{r}\mathrm{n} \\
\text { mean } \\
\mathrm{sd} \\
\min \\
\max \end{array}$ & $\begin{array}{l}3 \\
9.5 \\
0.67 \\
8.8 \\
10.2\end{array}$ & $\begin{array}{l}4 \\
9.7 \\
0.56 \\
9.3 \\
10.5\end{array}$ & $\begin{array}{l}5 \\
9.6 \\
0.17 \\
9.4 \\
9.8\end{array}$ & $\begin{array}{l}5 \\
9.3 \\
0.38 \\
8.7 \\
9.6\end{array}$ & $\begin{array}{l}4 \\
8.2 \\
0.32 \\
7.9 \\
8.6\end{array}$ & 0 & $\begin{array}{l}11 \\
8.9 \\
0.35 \\
8.3 \\
9.4\end{array}$ & $\begin{array}{l}10 \\
8.7 \\
0.32 \\
8.3 \\
9.3\end{array}$ & $\begin{array}{l}3 \\
8.6 \\
0.29 \\
8.4 \\
9.0\end{array}$ & $\begin{array}{l}9 \\
8.6 \\
0.32 \\
8.1 \\
9.0\end{array}$ & $\begin{array}{l}10 \\
8.6 \\
0.18 \\
8.4 \\
8.9\end{array}$ & $\begin{array}{l}3 \\
8.5 \\
0.39 \\
8.1 \\
8.8\end{array}$ & $\begin{array}{l}2 \\
8.9 \\
0.06 \\
8.9 \\
9.0\end{array}$ & $\begin{array}{l}3 \\
8.4 \\
0.09 \\
8.3 \\
8.4\end{array}$ & 0 & 0 & $\begin{array}{l}6 \\
9.3 \\
0.14 \\
9.0 \\
9.5\end{array}$ & $\begin{array}{l}9 \\
9.3 \\
0.34 \\
8.8 \\
9.9\end{array}$ \\
\hline BUW & $\begin{array}{r}\mathrm{n} \\
\text { mean } \\
\mathrm{sd} \\
\min \\
\max \end{array}$ & $\begin{array}{c}3 \\
11.0 \\
0.32 \\
10.7 \\
11.3\end{array}$ & $\begin{array}{c}4 \\
11.2 \\
0.28 \\
10.9 \\
11.6\end{array}$ & $\begin{array}{c}5 \\
11.5 \\
0.25 \\
11.3 \\
11.9\end{array}$ & $\begin{array}{c}5 \\
11.1 \\
0.47 \\
10.4 \\
11.5\end{array}$ & $\begin{array}{c}4 \\
10.2 \\
0.27 \\
9.9 \\
10.5\end{array}$ & 0 & $\begin{array}{l}12 \\
10.7 \\
0.35 \\
10.0 \\
11.2\end{array}$ & $\begin{array}{l}10 \\
10.7 \\
0.47 \\
10.1 \\
11.4\end{array}$ & $\begin{array}{c}4 \\
10.7 \\
0.30 \\
10.4 \\
11.1\end{array}$ & $\begin{array}{c}9 \\
10.7 \\
0.29 \\
10.3 \\
11.2\end{array}$ & $\begin{array}{c}10 \\
10.5 \\
0.32 \\
9.9 \\
10.8\end{array}$ & $\begin{array}{c}3 \\
10.3 \\
0.28 \\
10.0 \\
10.5\end{array}$ & $\begin{array}{c}2 \\
11.0 \\
0.24 \\
10.8 \\
11.2\end{array}$ & $\begin{array}{c}3 \\
10.3 \\
0.36 \\
9.9 \\
10.7\end{array}$ & 0 & 0 & $\begin{array}{c}5 \\
11.6 \\
0.58 \\
10.8 \\
12.4\end{array}$ & $\begin{array}{c}9 \\
11.4 \\
0.42 \\
10.7 \\
12.1\end{array}$ \\
\hline BL & $\begin{array}{r}\mathrm{n} \\
\text { mean } \\
\mathrm{sd} \\
\min \\
\max \end{array}$ & $\begin{array}{c}3 \\
20.1 \\
1.48 \\
18.5 \\
21.3\end{array}$ & $\begin{array}{c}3 \\
20.9 \\
0.57 \\
20.3 \\
21.4 \\
\end{array}$ & $\begin{array}{c}5 \\
22.0 \\
1.48 \\
21.1 \\
24.6 \\
\end{array}$ & $\begin{array}{c}4 \\
20.9 \\
1.21 \\
19.4 \\
22.4\end{array}$ & $\begin{array}{c}4 \\
18.3 \\
0.87 \\
17.2 \\
19.2\end{array}$ & 0 & $\begin{array}{c}11 \\
19.5 \\
1.06 \\
17.9 \\
21.0\end{array}$ & $\begin{array}{l}10 \\
19.2 \\
1.24 \\
17.4 \\
21.5\end{array}$ & $\begin{array}{c}6 \\
19.6 \\
0.79 \\
18.3 \\
20.5\end{array}$ & $\begin{array}{c}8 \\
20.0 \\
0.59 \\
19.1 \\
20.9\end{array}$ & $\begin{array}{l}10 \\
19.5 \\
0.70 \\
18.6 \\
20.7\end{array}$ & $\begin{array}{c}3 \\
19.0 \\
0.16 \\
18.8 \\
19.1\end{array}$ & $\begin{array}{c}2 \\
20.3 \\
0.80 \\
19.7 \\
20.8\end{array}$ & $\begin{array}{c}3 \\
18.5 \\
0.55 \\
18.0 \\
19.1\end{array}$ & 0 & 0 & $\begin{array}{c}6 \\
21.6 \\
0.43 \\
21.0 \\
22.1\end{array}$ & $\begin{array}{c}9 \\
21.1 \\
0.86 \\
19.5 \\
22.5\end{array}$ \\
\hline PL & $\begin{array}{r}n \\
\text { mean } \\
\text { sd } \\
\min \\
\max \end{array}$ & $\begin{array}{c}3 \\
12.7 \\
1.00 \\
11.6 \\
13.4\end{array}$ & $\begin{array}{c}4 \\
13.5 \\
0.57 \\
12.8 \\
14.0\end{array}$ & $\begin{array}{c}5 \\
14.1 \\
0.80 \\
13.6 \\
15.5\end{array}$ & $\begin{array}{c}5 \\
13.5 \\
0.78 \\
12.4 \\
14.4\end{array}$ & $\begin{array}{c}4 \\
11.6 \\
0.47 \\
11.2 \\
12.1\end{array}$ & 0 & $\begin{array}{c}12 \\
12.2 \\
0.68 \\
11.0 \\
13.1\end{array}$ & $\begin{array}{l}10 \\
12.2 \\
0.67 \\
11.2 \\
13.3\end{array}$ & $\begin{array}{c}6 \\
12.4 \\
0.53 \\
11.6 \\
13.0\end{array}$ & $\begin{array}{c}9 \\
12.8 \\
0.32 \\
12.3 \\
13.2\end{array}$ & $\begin{array}{l}10 \\
12.3 \\
0.50 \\
11.7 \\
13.3\end{array}$ & $\begin{array}{c}3 \\
12.1 \\
0.43 \\
11.7 \\
12.5\end{array}$ & $\begin{array}{c}2 \\
12.0 \\
0.42 \\
11.7 \\
12.3\end{array}$ & $\begin{array}{c}3 \\
11.7 \\
0.51 \\
11.1 \\
12.1\end{array}$ & 0 & 0 & $\begin{array}{c}7 \\
13.3 \\
0.41 \\
12.5 \\
13.8\end{array}$ & $\begin{array}{c}9 \\
13.0 \\
0.69 \\
11.8 \\
14.0\end{array}$ \\
\hline $\mathrm{M}^{1} \mathrm{~L}$ & $\begin{array}{r}n \\
\text { mean } \\
\text { sd } \\
\min \\
\max \end{array}$ & $\begin{array}{l}3 \\
2.5 \\
0.04 \\
2.4 \\
2.5\end{array}$ & $\begin{array}{l}4 \\
2.5 \\
0.09 \\
2.4 \\
2.6\end{array}$ & $\begin{array}{l}5 \\
2.5 \\
0.07 \\
2.4 \\
2.6\end{array}$ & $\begin{array}{l}5 \\
2.4 \\
0.10 \\
2.3 \\
2.6\end{array}$ & $\begin{array}{l}4 \\
2.3 \\
0.13 \\
2.1 \\
2.4\end{array}$ & 0 & $\begin{array}{l}12 \\
2.4 \\
0.10 \\
2.2 \\
2.5\end{array}$ & $\begin{array}{l}10 \\
2.3 \\
0.14 \\
2.1 \\
2.6\end{array}$ & $\begin{array}{l}6 \\
2.4 \\
0.11 \\
2.2 \\
2.5\end{array}$ & $\begin{array}{l}9 \\
2.4 \\
0.11 \\
2.2 \\
2.6\end{array}$ & $\begin{array}{l}10 \\
2.4 \\
0.11 \\
2.3 \\
2.7\end{array}$ & $\begin{array}{l}3 \\
2.4 \\
0.05 \\
2.3 \\
2.4\end{array}$ & $\begin{array}{l}2 \\
2.4 \\
0.02 \\
2.4 \\
2.4\end{array}$ & $\begin{array}{l}3 \\
2.3 \\
0.10 \\
2.2 \\
2.3\end{array}$ & 0 & 0 & $\begin{array}{l}7 \\
2.2 \\
0.15 \\
2.0 \\
2.4\end{array}$ & $\begin{array}{l}9 \\
2.2 \\
0.13 \\
2.0 \\
2.3\end{array}$ \\
\hline $\mathrm{M}^{2} \mathrm{~L}$ & $\begin{array}{r}n \\
\text { mean } \\
\mathrm{sd} \\
\min \\
\max \end{array}$ & $\begin{array}{l}3 \\
0.7 \\
0.05 \\
0.7 \\
0.8\end{array}$ & $\begin{array}{l}4 \\
0.8 \\
0.09 \\
0.7 \\
0.9\end{array}$ & $\begin{array}{l}5 \\
0.8 \\
0.03 \\
0.8 \\
0.9\end{array}$ & $\begin{array}{l}5 \\
0.8 \\
0.04 \\
0.7 \\
0.8\end{array}$ & $\begin{array}{l}4 \\
0.7 \\
0.09 \\
0.6 \\
0.8\end{array}$ & 0 & $\begin{array}{l}12 \\
0.7 \\
0.07 \\
0.6 \\
0.9\end{array}$ & $\begin{array}{l}10 \\
0.7 \\
0.06 \\
0.6 \\
0.8\end{array}$ & $\begin{array}{l}6 \\
0.7 \\
0.07 \\
0.6 \\
0.8\end{array}$ & $\begin{array}{l}9 \\
0.7 \\
0.07 \\
0.6 \\
0.8\end{array}$ & $\begin{array}{l}10 \\
0.7 \\
0.05 \\
0.6 \\
0.8\end{array}$ & $\begin{array}{l}3 \\
0.7 \\
0.06 \\
0.7 \\
0.8\end{array}$ & $\begin{array}{l}2 \\
0.7 \\
0.06 \\
0.6 \\
0.7\end{array}$ & $\begin{array}{l}3 \\
0.6 \\
0.06 \\
0.6 \\
0.7\end{array}$ & 0 & 0 & $\begin{array}{l}7 \\
0.8 \\
0.07 \\
0.7 \\
1.0\end{array}$ & $\begin{array}{l}9 \\
0.8 \\
0.07 \\
0.7 \\
0.9\end{array}$ \\
\hline$M^{1} W$ & $\begin{array}{r}n \\
\text { mean } \\
\text { sd } \\
\min \\
\max \end{array}$ & $\begin{array}{l}3 \\
1.5 \\
0.02 \\
1.5 \\
1.5\end{array}$ & $\begin{array}{l}4 \\
1.5 \\
0.11 \\
1.4 \\
1.6\end{array}$ & $\begin{array}{l}5 \\
1.6 \\
0.04 \\
1.6 \\
1.7\end{array}$ & $\begin{array}{l}5 \\
1.5 \\
0.07 \\
1.5 \\
1.6\end{array}$ & $\begin{array}{l}4 \\
1.4 \\
0.05 \\
1.3 \\
1.4\end{array}$ & 0 & $\begin{array}{l}12 \\
1.4 \\
0.05 \\
1.3 \\
1.5\end{array}$ & $\begin{array}{l}10 \\
1.4 \\
0.07 \\
1.2 \\
1.4\end{array}$ & $\begin{array}{l}6 \\
1.4 \\
0.09 \\
1.2 \\
1.5\end{array}$ & $\begin{array}{l}9 \\
1.4 \\
0.06 \\
1.3 \\
1.5\end{array}$ & $\begin{array}{l}10 \\
1.4 \\
0.05 \\
1.3 \\
1.5\end{array}$ & $\begin{array}{l}3 \\
1.4 \\
0.04 \\
1.3 \\
1.4\end{array}$ & $\begin{array}{l}2 \\
1.4 \\
0.04 \\
1.4 \\
1.5\end{array}$ & $\begin{array}{l}3 \\
1.4 \\
0.07 \\
1.3 \\
1.4\end{array}$ & 0 & 0 & $\begin{array}{l}7 \\
1.5 \\
0.06 \\
1.4 \\
1.5\end{array}$ & $\begin{array}{l}9 \\
1.4 \\
0.05 \\
1.4 \\
1.5\end{array}$ \\
\hline
\end{tabular}


Appendix 3 (cont.)

\begin{tabular}{|c|c|c|c|c|c|c|c|c|c|c|c|c|c|c|c|c|c|c|c|}
\hline \multirow[t]{2}{*}{ Variable } & \multirow[t]{2}{*}{ Statistic } & \multicolumn{2}{|c|}{ Pilbara } & \multicolumn{2}{|c|}{$\begin{array}{c}\text { Thevenard } \\
\text { Island }\end{array}$} & \multicolumn{2}{|c|}{$\begin{array}{c}\text { Great Sandy } \\
\text { Desert }\end{array}$} & \multicolumn{2}{|c|}{$\begin{array}{c}\text { Mount } \\
\text { Percy }\end{array}$} & \multicolumn{2}{|c|}{$\begin{array}{l}\text { Mitchell } \\
\text { Plateau }\end{array}$} & \multicolumn{2}{|c|}{ Lissadell } & \multicolumn{2}{|c|}{ Kakadu } & \multicolumn{2}{|c|}{ Queensland } & \multicolumn{2}{|c|}{ L. forresti } \\
\hline & & $\mathrm{F}$ & $\mathrm{M}$ & $\mathrm{F}$ & $\mathrm{M}$ & $\mathrm{F}$ & $M$ & $\mathrm{~F}$ & $\mathrm{M}$ & $\mathrm{F}$ & $\mathrm{M}$ & $\mathrm{F}$ & $\mathrm{M}$ & $\mathrm{F}$ & $\mathrm{M}$ & $\mathrm{F}$ & M & $\mathrm{F}$ & $\mathrm{M}$ \\
\hline$M^{1} M^{3} L$ & $\begin{array}{r}\mathrm{n} \\
\text { mean } \\
\mathrm{sd} \\
\min \\
\max \end{array}$ & $\begin{array}{l}3 \\
4.5 \\
0.10 \\
4.4 \\
4.6\end{array}$ & $\begin{array}{l}4 \\
4.6 \\
0.10 \\
4.5 \\
4.7\end{array}$ & $\begin{array}{l}5 \\
4.6 \\
0.06 \\
4.5 \\
4.7\end{array}$ & $\begin{array}{l}5 \\
4.5 \\
0.06 \\
4.4 \\
4.5\end{array}$ & $\begin{array}{l}4 \\
4.0 \\
0.22 \\
3.8 \\
4.3\end{array}$ & 0 & $\begin{array}{l}12 \\
4.3 \\
0.17 \\
4.0 \\
4.5 \\
\end{array}$ & $\begin{array}{l}10 \\
4.2 \\
0.25 \\
3.9 \\
4.6 \\
\end{array}$ & $\begin{array}{l}6 \\
4.3 \\
0.22 \\
3.9 \\
4.4\end{array}$ & $\begin{array}{l}9 \\
4.3 \\
0.11 \\
4.2 \\
4.5\end{array}$ & $\begin{array}{l}10 \\
4.3 \\
0.12 \\
4.1 \\
4.5\end{array}$ & $\begin{array}{l}3 \\
4.2 \\
0.13 \\
4.1 \\
4.4\end{array}$ & $\begin{array}{l}2 \\
4.1 \\
0.11 \\
4.0 \\
4.2\end{array}$ & $\begin{array}{l}3 \\
4.0 \\
0.16 \\
3.8 \\
4.1\end{array}$ & 0 & 0 & $\begin{array}{l}7 \\
4.4 \\
0.17 \\
4.1 \\
4.7 \\
\end{array}$ & $\begin{array}{l}9 \\
4.4 \\
0.20 \\
4.1 \\
4.7 \\
\end{array}$ \\
\hline APF & $\begin{array}{r}\mathrm{n} \\
\text { mean } \\
\mathrm{sd} \\
\min \\
\max \end{array}$ & $\begin{array}{l}3 \\
5.2 \\
0.53 \\
4.6 \\
5.5 \\
\end{array}$ & $\begin{array}{l}4 \\
5.1 \\
0.53 \\
4.7 \\
5.9 \\
\end{array}$ & $\begin{array}{l}5 \\
5.6 \\
0.46 \\
5.0 \\
6.1 \\
\end{array}$ & $\begin{array}{l}5 \\
5.2 \\
0.52 \\
4.4 \\
5.7 \\
\end{array}$ & $\begin{array}{l}4 \\
5.3 \\
0.30 \\
4.8 \\
5.5 \\
\end{array}$ & 0 & $\begin{array}{l}12 \\
5.0 \\
0.52 \\
4.0 \\
5.6 \\
\end{array}$ & $\begin{array}{l}10 \\
5.1 \\
0.39 \\
4.5 \\
5.6 \\
\end{array}$ & $\begin{array}{l}6 \\
5.3 \\
0.31 \\
4.9 \\
5.8 \\
\end{array}$ & $\begin{array}{l}9 \\
5.4 \\
0.16 \\
5.2 \\
5.6 \\
\end{array}$ & $\begin{array}{l}10 \\
5.1 \\
0.35 \\
4.5 \\
5.5 \\
\end{array}$ & $\begin{array}{l}3 \\
5.5 \\
0.08 \\
5.4 \\
5.5 \\
\end{array}$ & $\begin{array}{l}2 \\
5.2 \\
0.29 \\
5.0 \\
5.4 \\
\end{array}$ & $\begin{array}{l}3 \\
4.7 \\
0.43 \\
4.4 \\
5.2 \\
\end{array}$ & 0 & 0 & $\begin{array}{l}7 \\
5.2 \\
0.22 \\
5.0 \\
5.5\end{array}$ & $\begin{array}{l}9 \\
5.4 \\
0.52 \\
4.7 \\
6.6\end{array}$ \\
\hline CIL & $\begin{array}{r}\mathrm{n} \\
\text { mean } \\
\mathrm{sd} \\
\min \\
\max \end{array}$ & $\begin{array}{c}3 \\
15.5 \\
0.62 \\
14.8 \\
15.9\end{array}$ & $\begin{array}{c}4 \\
16.4 \\
0.66 \\
15.6 \\
17.2 \\
\end{array}$ & $\begin{array}{c}5 \\
17.0 \\
0.74 \\
16.5 \\
18.3 \\
\end{array}$ & $\begin{array}{c}5 \\
16.2 \\
0.87 \\
14.9 \\
17.3 \\
\end{array}$ & $\begin{array}{c}4 \\
14.6 \\
0.61 \\
13.9 \\
15.1 \\
\end{array}$ & 0 & $\begin{array}{c}12 \\
15.1 \\
0.84 \\
13.7 \\
16.3 \\
\end{array}$ & $\begin{array}{l}10 \\
15.3 \\
1.04 \\
13.6 \\
17.1 \\
\end{array}$ & $\begin{array}{c}5 \\
16.0 \\
0.42 \\
15.5 \\
16.4\end{array}$ & $\begin{array}{c}9 \\
16.2 \\
0.55 \\
15.5 \\
16.9\end{array}$ & $\begin{array}{c}10 \\
15.3 \\
0.70 \\
14.0 \\
16.3\end{array}$ & $\begin{array}{c}3 \\
14.9 \\
0.33 \\
14.6 \\
15.2\end{array}$ & $\begin{array}{c}2 \\
15.9 \\
0.71 \\
15.4 \\
16.4\end{array}$ & $\begin{array}{c}3 \\
14.6 \\
0.57 \\
13.9 \\
15.0\end{array}$ & 0 & 0 & $\begin{array}{c}5 \\
16.0 \\
0.41 \\
15.4 \\
16.5 \\
\end{array}$ & $\begin{array}{c}9 \\
15.9 \\
0.70 \\
14.6 \\
16.8 \\
\end{array}$ \\
\hline CAL & $\begin{array}{r}n \\
\text { mean } \\
\text { sd } \\
\min \\
\max \end{array}$ & $\begin{array}{l}3 \\
5.8 \\
0.55 \\
5.2 \\
6.2\end{array}$ & $\begin{array}{l}4 \\
6.0 \\
0.60 \\
5.2 \\
6.5 \\
\end{array}$ & $\begin{array}{l}5 \\
6.0 \\
0.36 \\
5.6 \\
6.6 \\
\end{array}$ & $\begin{array}{l}4 \\
5.8 \\
0.57 \\
5.1 \\
6.5\end{array}$ & $\begin{array}{l}4 \\
5.1 \\
0.47 \\
4.5 \\
5.6\end{array}$ & 0 & $\begin{array}{l}11 \\
5.5 \\
0.44 \\
4.9 \\
6.2 \\
\end{array}$ & $\begin{array}{l}9 \\
5.7 \\
0.68 \\
4.7 \\
6.7\end{array}$ & $\begin{array}{l}5 \\
5.5 \\
0.18 \\
5.4 \\
5.8\end{array}$ & $\begin{array}{l}8 \\
6.0 \\
0.50 \\
5.2 \\
7.0\end{array}$ & $\begin{array}{l}9 \\
5.4 \\
0.29 \\
5.0 \\
5.9\end{array}$ & $\begin{array}{l}3 \\
5.3 \\
0.15 \\
5.2 \\
5.5\end{array}$ & $\begin{array}{l}2 \\
5.9 \\
0.11 \\
5.9 \\
6.0\end{array}$ & $\begin{array}{l}1 \\
4.8 \\
4.8 \\
4.8\end{array}$ & 0 & 0 & $\begin{array}{l}5 \\
6.3 \\
0.26 \\
6.0 \\
6.5\end{array}$ & $\begin{array}{l}7 \\
5.7 \\
0.21 \\
5.5 \\
6.0\end{array}$ \\
\hline $\mathrm{M}_{1} \mathrm{M}_{3} \mathrm{~L}$ & $\begin{array}{r}n \\
\text { mean } \\
\text { sd } \\
\min \\
\max \end{array}$ & $\begin{array}{l}3 \\
3.6 \\
0.10 \\
3.5 \\
3.7\end{array}$ & $\begin{array}{l}4 \\
3.8 \\
0.14 \\
3.6 \\
4.0\end{array}$ & $\begin{array}{l}5 \\
3.8 \\
0.21 \\
3.5 \\
4.0\end{array}$ & $\begin{array}{l}5 \\
3.8 \\
0.16 \\
3.7 \\
4.0\end{array}$ & $\begin{array}{l}4 \\
3.3 \\
0.16 \\
3.2 \\
3.5 \\
\end{array}$ & 0 & $\begin{array}{l}12 \\
3.5 \\
0.19 \\
3.2 \\
3.8 \\
\end{array}$ & $\begin{array}{l}10 \\
3.4 \\
0.18 \\
3.1 \\
3.7 \\
\end{array}$ & $\begin{array}{l}5 \\
3.4 \\
0.20 \\
3.1 \\
3.7\end{array}$ & $\begin{array}{l}9 \\
3.5 \\
0.12 \\
3.3 \\
3.7\end{array}$ & $\begin{array}{l}10 \\
3.4 \\
0.10 \\
3.2 \\
3.6\end{array}$ & $\begin{array}{l}3 \\
3.3 \\
0.21 \\
3.1 \\
3.5\end{array}$ & $\begin{array}{l}2 \\
3.4 \\
0.11 \\
3.3 \\
3.4\end{array}$ & $\begin{array}{l}3 \\
3.4 \\
0.13 \\
3.3 \\
3.5\end{array}$ & 0 & 0 & $\begin{array}{l}6 \\
3.6 \\
0.09 \\
3.5 \\
3.8 \\
\end{array}$ & $\begin{array}{l}9 \\
3.6 \\
0.10 \\
3.5 \\
3.8 \\
\end{array}$ \\
\hline HV & $\begin{array}{r}n \\
\text { mean } \\
\mathrm{sd} \\
\min \\
\max \end{array}$ & $\begin{array}{c}3 \\
59.8 \\
7.12 \\
51.8 \\
65.5\end{array}$ & $\begin{array}{l}3 \\
74.2 \\
10.31 \\
62.4 \\
81.3\end{array}$ & $\begin{array}{c}5 \\
82.2 \\
6.24 \\
77.5 \\
92.0\end{array}$ & \begin{tabular}{l}
\multicolumn{1}{c}{7} \\
76.3 \\
11.16 \\
56.0 \\
91.0
\end{tabular} & $\begin{array}{c}6 \\
63.5 \\
6.12 \\
56.7 \\
73.0 \\
\end{array}$ & 0 & $\begin{array}{l}13 \\
64.4 \\
11.33 \\
50.2 \\
84.8 \\
\end{array}$ & $\begin{array}{l}9 \\
67.0 \\
11.21 \\
52.0 \\
82.5 \\
\end{array}$ & $\begin{array}{c}5 \\
65.9 \\
6.40 \\
55.0 \\
70.2 \\
\end{array}$ & $\begin{array}{c}8 \\
64.2 \\
4.25 \\
57.7 \\
72.0 \\
\end{array}$ & $\begin{array}{c}9 \\
65.7 \\
5.89 \\
60.0 \\
75.3 \\
\end{array}$ & $\begin{array}{c}3 \\
63.8 \\
5.44 \\
60.0 \\
70.0 \\
\end{array}$ & $\begin{array}{c}2 \\
68.2 \\
2.19 \\
66.7 \\
69.8 \\
\end{array}$ & $\begin{array}{c}2 \\
73.1 \\
0.42 \\
72.8 \\
73.4 \\
\end{array}$ & $\begin{array}{c}3 \\
72.4 \\
2.87 \\
70.0 \\
75.6 \\
\end{array}$ & $\begin{array}{c}3 \\
74.9 \\
3.72 \\
70.8 \\
78.0 \\
\end{array}$ & $\begin{array}{c}6 \\
77.4 \\
1.40 \\
75.7 \\
79.4 \\
\end{array}$ & $\begin{array}{c}2 \\
73.8 \\
5.37 \\
70.0 \\
77.6 \\
\end{array}$ \\
\hline TV & $\begin{array}{r}\mathrm{n} \\
\text { mean } \\
\mathrm{sd} \\
\min \\
\max \end{array}$ & $\begin{array}{c}3 \\
56.8 \\
3.42 \\
53.2 \\
60.0\end{array}$ & $\begin{array}{c}4 \\
56.0 \\
7.77 \\
45.5 \\
64.3\end{array}$ & $\begin{array}{c}5 \\
75.0 \\
2.40 \\
72.5 \\
78.6\end{array}$ & $\begin{array}{c}7 \\
76.5 \\
4.75 \\
69.0 \\
83.4\end{array}$ & $\begin{array}{c}6 \\
52.9 \\
7.43 \\
46.9 \\
67.0\end{array}$ & 0 & $\begin{array}{l}13 \\
52.3 \\
4.29 \\
46.0 \\
58.3\end{array}$ & $\begin{array}{c}9 \\
51.7 \\
5.86 \\
42.0 \\
63.0\end{array}$ & $\begin{array}{c}5 \\
51.1 \\
3.85 \\
44.5 \\
54.6\end{array}$ & $\begin{array}{c}8 \\
51.8 \\
4.11 \\
47.0 \\
58.4\end{array}$ & $\begin{array}{c}8 \\
49.7 \\
4.61 \\
42.0 \\
55.0\end{array}$ & $\begin{array}{c}3 \\
53.6 \\
0.55 \\
53.0 \\
54.0\end{array}$ & $\begin{array}{c}2 \\
52.7 \\
3.46 \\
50.2 \\
55.1\end{array}$ & $\begin{array}{c}2 \\
54.0 \\
1.84 \\
52.7 \\
55.3\end{array}$ & $\begin{array}{c}3 \\
44.5 \\
4.88 \\
39.0 \\
48.3\end{array}$ & \begin{tabular}{l}
\multicolumn{1}{c}{3} \\
47.0 \\
10.51 \\
39.4 \\
59.0
\end{tabular} & $\begin{array}{c}6 \\
64.5 \\
2.83 \\
61.1 \\
69.3\end{array}$ & $\begin{array}{c}2 \\
59.0 \\
2.83 \\
57.0 \\
61.0\end{array}$ \\
\hline
\end{tabular}




\begin{tabular}{|c|c|c|c|c|c|c|c|c|c|c|c|c|c|c|c|c|c|c|c|}
\hline TAILW & $\begin{array}{r}\mathrm{n} \\
\text { mean } \\
\mathrm{sd} \\
\min \\
\max \end{array}$ & $\begin{array}{l}3 \\
2.5 \\
0.29 \\
2.2 \\
2.7\end{array}$ & $\begin{array}{l}4 \\
2.6 \\
0.19 \\
2.5 \\
2.9\end{array}$ & $\begin{array}{l}5 \\
3.2 \\
0.23 \\
3.0 \\
3.5\end{array}$ & $\begin{array}{l}7 \\
3.0 \\
0.65 \\
2.0 \\
3.7\end{array}$ & $\begin{array}{l}6 \\
2.1 \\
0.25 \\
1.7 \\
2.4\end{array}$ & 0 & $\begin{array}{l}13 \\
2.3 \\
0.24 \\
1.9 \\
2.7\end{array}$ & $\begin{array}{l}9 \\
2.3 \\
0.42 \\
1.6 \\
3.0\end{array}$ & $\begin{array}{l}5 \\
2.4 \\
0.29 \\
2.0 \\
2.8\end{array}$ & $\begin{array}{l}8 \\
2.2 \\
0.19 \\
2.0 \\
2.5\end{array}$ & $\begin{array}{l}9 \\
2.2 \\
0.23 \\
1.9 \\
2.5\end{array}$ & $\begin{array}{l}3 \\
2.6 \\
0.21 \\
2.4 \\
2.8\end{array}$ & $\begin{array}{l}2 \\
2.5 \\
0.21 \\
2.3 \\
2.6\end{array}$ & $\begin{array}{l}2 \\
2.3 \\
0.42 \\
2.0 \\
2.6\end{array}$ & $\begin{array}{l}3 \\
2.2 \\
0.21 \\
2.0 \\
2.4\end{array}$ & $\begin{array}{l}3 \\
2.4 \\
0.15 \\
2.3 \\
2.6\end{array}$ & $\begin{array}{l}6 \\
2.5 \\
0.17 \\
2.3 \\
2.8\end{array}$ & $\begin{array}{l}2 \\
2.7 \\
0.21 \\
2.5 \\
2.8\end{array}$ \\
\hline PESW & $\begin{array}{r}\mathrm{n} \\
\text { mean } \\
\mathrm{sd} \\
\min \\
\max \end{array}$ & $\begin{array}{l}3 \\
3.5 \\
0.25 \\
3.3 \\
3.8\end{array}$ & $\begin{array}{l}4 \\
3.4 \\
0.35 \\
3.2 \\
3.9\end{array}$ & $\begin{array}{l}5 \\
3.9 \\
0.26 \\
3.5 \\
4.2\end{array}$ & $\begin{array}{l}7 \\
3.9 \\
0.40 \\
3.3 \\
4.3\end{array}$ & $\begin{array}{l}6 \\
2.7 \\
0.15 \\
2.5 \\
2.9\end{array}$ & 0 & $\begin{array}{l}13 \\
3.0 \\
0.24 \\
2.6 \\
3.3\end{array}$ & $\begin{array}{l}9 \\
3.5 \\
0.32 \\
3.2 \\
4.1\end{array}$ & $\begin{array}{l}5 \\
3.2 \\
0.22 \\
3.0 \\
3.5\end{array}$ & $\begin{array}{l}8 \\
3.4 \\
0.47 \\
2.6 \\
4.0\end{array}$ & $\begin{array}{l}9 \\
2.9 \\
0.35 \\
2.4 \\
3.5\end{array}$ & $\begin{array}{l}3 \\
2.9 \\
0.17 \\
2.8 \\
3.1\end{array}$ & $\begin{array}{l}2 \\
2.6 \\
0.00 \\
2.6 \\
2.6\end{array}$ & $\begin{array}{l}2 \\
2.5 \\
0.07 \\
2.5 \\
2.6\end{array}$ & $\begin{array}{l}3 \\
2.9 \\
0.06 \\
2.9 \\
3.0\end{array}$ & $\begin{array}{l}3 \\
3.1 \\
0.26 \\
2.8 \\
3.3\end{array}$ & $\begin{array}{l}6 \\
3.3 \\
0.30 \\
2.9 \\
3.7\end{array}$ & $\begin{array}{l}2 \\
3.2 \\
0.35 \\
3.0 \\
3.5\end{array}$ \\
\hline PESL & $\begin{array}{r}\mathrm{n} \\
\text { mean } \\
\mathrm{sd} \\
\min \\
\max \end{array}$ & $\begin{array}{c}3 \\
16.5 \\
0.38 \\
16.1 \\
16.8\end{array}$ & $\begin{array}{c}4 \\
16.5 \\
0.43 \\
16.0 \\
17.0\end{array}$ & $\begin{array}{c}5 \\
19.0 \\
1.31 \\
17.5 \\
20.9\end{array}$ & $\begin{array}{c}7 \\
17.8 \\
0.47 \\
17.0 \\
18.4\end{array}$ & $\begin{array}{c}6 \\
13.9 \\
0.80 \\
13.0 \\
15.2\end{array}$ & 0 & $\begin{array}{l}13 \\
14.9 \\
0.93 \\
13.8 \\
17.2\end{array}$ & $\begin{array}{c}9 \\
14.8 \\
1.09 \\
13.3 \\
16.8\end{array}$ & $\begin{array}{c}5 \\
15.9 \\
0.81 \\
14.7 \\
16.7\end{array}$ & $\begin{array}{c}8 \\
15.3 \\
0.71 \\
13.7 \\
16.1\end{array}$ & $\begin{array}{c}9 \\
14.6 \\
0.44 \\
14.1 \\
15.5\end{array}$ & $\begin{array}{c}3 \\
13.5 \\
1.12 \\
12.5 \\
14.7\end{array}$ & $\begin{array}{c}2 \\
13.8 \\
1.20 \\
12.9 \\
14.6\end{array}$ & $\begin{array}{c}2 \\
14.6 \\
0.99 \\
13.9 \\
15.3\end{array}$ & $\begin{array}{c}3 \\
15.3 \\
0.70 \\
14.6 \\
16.0\end{array}$ & $\begin{array}{c}3 \\
15.6 \\
1.39 \\
14.4 \\
17.1\end{array}$ & $\begin{array}{c}6 \\
17.1 \\
0.90 \\
16.1 \\
18.1\end{array}$ & $\begin{array}{c}2 \\
16.2 \\
0.64 \\
15.7 \\
16.6\end{array}$ \\
\hline EARL & $\begin{array}{r}N \\
\text { mean } \\
\text { sd } \\
\min \\
\max \end{array}$ & $\begin{array}{c}3 \\
11.2 \\
0.53 \\
10.8 \\
11.8\end{array}$ & $\begin{array}{c}3 \\
11.7 \\
0.72 \\
10.9 \\
12.2\end{array}$ & $\begin{array}{c}5 \\
12.1 \\
0.77 \\
10.9 \\
13.0\end{array}$ & $\begin{array}{c}7 \\
11.4 \\
0.85 \\
10.3 \\
12.7\end{array}$ & $\begin{array}{l}5 \\
10.6 \\
0.50 \\
9.8 \\
11.0\end{array}$ & 0 & $\begin{array}{l}13 \\
10.2 \\
1.15 \\
8.3 \\
11.9\end{array}$ & $\begin{array}{l}9 \\
10.6 \\
1.01 \\
9.3 \\
12.3\end{array}$ & $\begin{array}{c}5 \\
12.1 \\
1.31 \\
10.6 \\
13.9\end{array}$ & $\begin{array}{c}8 \\
11.7 \\
0.80 \\
10.9 \\
13.4\end{array}$ & $\begin{array}{l}9 \\
11.0 \\
1.08 \\
9.6 \\
13.2\end{array}$ & $\begin{array}{l}3 \\
10.2 \\
0.59 \\
9.8 \\
10.9\end{array}$ & $\begin{array}{c}2 \\
11.3 \\
0.64 \\
10.8 \\
11.7\end{array}$ & $\begin{array}{c}2 \\
11.3 \\
0.35 \\
11.0 \\
11.5\end{array}$ & $\begin{array}{c}2 \\
10.6 \\
0.57 \\
10.2 \\
11.0\end{array}$ & $\begin{array}{c}3 \\
10.8 \\
0.98 \\
10.2 \\
11.9\end{array}$ & $\begin{array}{c}6 \\
12.3 \\
0.72 \\
11.5 \\
13.1\end{array}$ & $\begin{array}{c}2 \\
12.6 \\
0.00 \\
12.6 \\
12.6\end{array}$ \\
\hline
\end{tabular}

